\title{
Deciphering the Morphological, Physiological and Biochemical Mechanism Associated with Drought Stress Tolerance in Tomato Genotypes
}

\author{
Abida Parveen ${ }^{1}$, Gyanendra Kumar Rai ${ }^{*}$, Muntazir Mushtaq ${ }^{1}$, Monika Singh ${ }^{2}$, \\ Pradeep K. Rai ${ }^{3}$, Sunil K. Rai ${ }^{4}$ and Ajaz Ahmad Kundoo ${ }^{5}$ \\ ${ }^{1}$ Sher-e-Kashmir University of Agricultural Sciences and Technology of Jammu, \\ Jammu and Kashmir, 180009, India \\ ${ }^{2}$ G.L. Bajaj Institute of Technology and Management, Greater Noida, GB Nagar, \\ Uttar Pradesh, 201306, India \\ ${ }^{3}$ Advance Center for Horticulture Research, Sher-e-Kashmir University of Agricultural \\ Sciences and Technology of Jammu, 180009, India \\ ${ }^{4}$ Division of Plant Breeding and Genetics, Sher-e-Kashmir University of Agricultural Sciences \\ and Technology of Jammu, 180009, India \\ ${ }^{5}$ Division of Entomology, Sher-e-Kashmir University of Agricultural Sciences and Technology \\ of Srinagar, Shalimar, 190001, India \\ *Corresponding author
}

\section{Keywords \\ Tomato, Drought, Morphology, Physiology, Ascorbic acid, Proline \\ Article Info \\ Accepted: 04 April 2019 Available Online: 10 May 2019}

\section{A B S T R A C T}

Abiotic stresses are one of the key limitations to global crop production and food security. Among the abiotic stresses, drought is one of the most vital factors that causes change in morphological, biochemical and physiological characteristics in plants, and consequently affects the growth and productivity of crops. The main purpose of the present study was to evaluate the effect of drought on morphological [Plant height, root length $(\mathrm{cm})$, shoot length $(\mathrm{cm})$, number of branches, yield attributing traits], physiological ratio of root/shoot length, leaf area $\left(\mathrm{cm}^{2}\right)$, relative water content $(\%)$, and electrolyte leakage (\% conductivity) and biochemical traits [ascorbic acid content $(\mathrm{mg} / 100 \mathrm{~g})$, total carotenoids $(\mathrm{mg} / 100 \mathrm{~g})$, total chlorophyll content, proline, sugar content] in 15 tomato genotypes and to identify drought stress tolerant genotypes. The results confirmed that there are significant variations in agronomic, physiological and biochemical parameters among 15 tomato genotypes under drought and irrigated conditions. Among the 15 genotypes, EC-317-6-1 and WIR-4360 were found highly tolerant to drought in comparison to others while Kashi Amrit and Kashi Sharad were found susceptible to drought conditions. The performance of tomato genotypes used in the study showed significant differences in all studied traits, suggesting that they could be taken into account when selecting for drought tolerance. EC-317-6-171 and WIR-4360 had good yield performance under deficit irrigation treatment. Moreover, results indicate that biochemical and physiological parameters are more useful for the screening of drought tolerant tomato genotypes. 


\section{Introduction}

Tomato are a major source of antioxidants such as carotenoids, including lycopene and beta carotene, vitamin-C, vitamin-E and polyphenols such as Kaempferol and quercetin, a notable capacity to eliminate active oxygen species (AOS) (Rao et al., 1998; Rai et al., 2012). Ascorbic acid being an antioxidant directly eliminates superoxide, hydroxyl radicals, oxygen singlet radicals and reduces hydrogen peroxide (Rai et al., 2012). Lycopene is a carotenoid that accounts for the reddening of tomato due to the differentiation of the chloroplasts and chromoplasts, so lycopene contributes to the nutritional and marketable quality of this plant product (Dumas et al., 2003). Various research findings have demonstrated the direct correlation of quality of the tomato with its lycopene content (Singh et al., 2004; Singh et al, 2007; George et al., 2004). Moreover, it is also well known that the mixture of antioxidants exert positive effect on health benefits, related to consumption of fresh fruits and vegetables. Due to its high consumption rates, tomato can provide the total intake of these components significantly (Abushita et al., 1997; Beecher, 1998).

Tomato is a popular and economically important vegetable species worldwide. Tomato consumption as well as production is permanently increasing because of its antioxidative and anti-cancerous properties (Raiola et al., 2014). In 2015, Tomato was $7^{\text {th }}$ globally in terms of production, accomplishing a world production of approximately 164,000,000.00 million tones on an area of nearly 4.8 million hectares (Gerszberg et al., 2016). Tomato is the second most important vegetable in terms of production worldwide due to its intense breeding programs (FOASTAT, 2014). In India, the tomato is cultivated on $0.458 \mathrm{M}$ ha area with $7.277 \mathrm{M} \mathrm{mt}$ production and
$15.9 \mathrm{mt} /$ ha productivity and the major tomato producing states in the country are Andhra Pradesh, Madhya Pradesh, Karnataka, Gujarat, Odisha, West Bengal, Chhattisgarh, Maharashtra, Bihar, Haryana, Uttar Pradesh, Telangana and Tamil Nadu (State Departments of Agriculture and Horticulture, 2018). Being agriculturally and economically important crop and due its complete genome sequencing, tomato is considered to be a preeminent model for genetics, breeding and genomics studies (Choudhary et al., 2018). Feeding the world is a most important challenge under climate change scenario and increased water scarcity, which is further exacerbated due to growing global population (Lesk et al., 2016). Moreover, various environmental stresses especially extreme temperature, drought, salinity and inadequate moisture impaired global crop productivity. Temperature between 25 to $30^{\circ} \mathrm{C}$ during the day and $20^{\circ} \mathrm{C}$ at night is the optimum for tomato cultivation. Average global temperatures are rising by approximately $0.3^{\circ} \mathrm{C}$ per decade. Due to a $2-4^{\circ} \mathrm{C}$ increase over the optimal $\left(25^{\circ} \mathrm{C}\right)$ temperature, plant growth, embryo development, flowering, gamete development, seed germination, fruit ripening, ability of pollinated flowers to develop into seeded fruit, and consequently the yield are adversely affected (Solankey et al., 2015). Drought, an another important natural disaster for tomato production and its quality, resulting from prolonged shortage in rainfall, often accompanied by quite high temperature affects photosynthesis and ultimately reduces crop productivity.

Drought often causes adaptive changes in plant growth and physio-biochemical processes such as changes in plant structure, growth rate, issue osmotic potential and antioxidant defenses (Kusvuran and Dasgan, 2017). Plants develop a wide range of strategies to avoid or tolerate water deficit. In order to circumvent water deficit condition, 
plants maintain high water status either by efficient water absorption from roots or by reducing evapo-transpiration from aerial parts. In case of drought tolerance, plants maintain turgor and continue metabolism even at low water potential through synthesis of osmoprotectants, osmolytes or compatible solutes or by protoplasmic tolerance (Mishra et al., 2012). Initially, drought stress closes stomata to diminish water loss by abscisic acid mediated process. Drought causes the excessive generation of reactive oxygen species (ROS) resulting into progressive oxidative damage and ultimately cell death (Rai et al., 2018). Tomatoes contribute to antioxidants, such as carotenoids (especially $\beta$-carotene and lycopene), phenolics, ascorbic acid (vitamin C) and small amounts of vitamin $\mathrm{E}$ on a daily basis. Scavenging of excessive ROS is accomplished by a competent antioxidative defense system consisting of the non-enzymic as well as enzymic antioxidants (Baxter et al., 2012). Various studies have reported that various environmental stresses induce increased amount of antioxidant phytochemicals and osmolytes against oxidative stress. The maintenance of high antioxidant capacity to detoxify the toxic ROS directly results into increased tolerance to environmental stresses (Kusvuran et al., 2016). In this perspective, it is supposed to obtain an increase in the plant protective mechanisms with simultaneous increase in several components of antioxidative defense system (SanchezRodriguez et al., 2010).

Plant secondary metabolites are often considered to as compounds that play central role in plant-environment interaction for adaptation and defense (Ramakrishna and Ravishankar, 2011). When subjected to various stresses including different elicitors or signal molecules, plants often tend to accumulate secondary metabolites (Bennet and Wallsgrove, 1994). Various studies demonstrated that drought often causes oxidative stress and leads to enhance amount of flavonoids and phenolic acids in willow leaves. Polyphenolic compounds are widely present in plants and are known for their overall antioxidant activity (Ramakrishna and Ravishankar, 2011). Environmental stress often induces production of phenolic metabolites such as flavonoids, lignin, tannins, hydroxycinnamate esters that serve specific roles in plant protection (Hernandez et al., 2004).

The purpose of this study was to assess morphological, physiological and biochemical mechanisms adapted by fifteen tomato genotypes which differing to tolerate drought and assess whether a certain degree of drought stress could enhance the antioxidant phytochemicals, carotenoids, chlorophyll, proline and sugar contents of tolerant and sensitive tomato genotypes.

\section{Materials and Methods}

Fifteen tomato genotypes were used in this research for the identification of tolerant tomato lines. Seed material of all the fifteen tomato genotypes was obtained from IIVR, Varanasi. All the selected genotypes with their source are enlisted in Table 1. Pot experiments were carried out in a controlled conditions (temperature: $25^{\circ} \mathrm{C} \pm 2$ and relative humidity: $55 \% \pm 5$ ) at School of Biotechnology, Sher-e-Kashmir University of Agricultural Sciences and Technology. The plants were subjected to drought stress at growth stage (45 days) till temporary wilting point and irrigated plants were grown under non-stress conditions for the same period of time.

Responses of the genotypes to drought were evaluated using some plant morphological (Plant height, root length $(\mathrm{cm})$, shoot length (cm) number of branches, and yield 
attributing characters), physiological (ratio of root/shoot length, leaf area $\left(\mathrm{cm}^{2}\right)$, relative water content $(\%)$, and electrolyte leakage (\% conductivity) and biochemical parameters such as ascorbic acid content (mg/100g), total carotenoids $(\mathrm{mg} / 100 \mathrm{~g})$, total chlorophyll content and proline. Observations were recorded on 11 economic traits from five randomly selected competitive plants of 15 genotypes in 5 replications and their mean were worked out for statistical analysis. Plant height was measured in centimeters from the base of the plant to tip of the main shoot at the time of final picking and average plant height of each genotype was worked out. Number of branches originating from the main stem was counted and has been determined as an average number of productive primary branches from ten randomly sampled plants at maturity. Root length was measured from the bottom of the shoot to top of the root. Number of flowers per cluster was counted manually starting from bottom to top in each cluster and on every branch of a plant. Number of cluster per plant was counted manually starting from bottom to top on each branch plant. Number of fruits per plant was counted manually starting from the down to up in each cluster and on every branch of a plant. Fruit setting percentage was calculated by dividing number of fruits per cluster with number of flowers per cluster and then multiplying the product with 100 . Root/shoot length ratio was calculated by dividing the root length by shoot length. Leaf area was calculated with the help of graph paper. Leaves to be measured were layered on a $1 \mathrm{~cm}$ grid and outline was traced. The number of partial squares was estimated and partial squares that are less than half covered were not counted. The area of stem (petiole) was not included in the calculations. Relative water content (RWC) in the leaves was calculated according to the formula (Bars and Weatherly, 1962): RWC $(\%)=[($ fresh weight - dry weight $) /$ (saturated weight - dry weight)]. The leaf dry weight was measured after oven drying at $105^{\circ} \mathrm{C}$ for $24 \mathrm{~h}$, and the saturated weight was measured after incubating the leaves in moist filter paper for $24 \mathrm{~h}$ in petri dishes at room temperature. The total ions leaked out of the leaf were estimated by the method described by Ben (Hamed et al., 2007). The electrolyte leakage was calculated using formula: Electrolyte leakage\% $=(\mathrm{ECb}-\mathrm{ECc} / \mathrm{ECa}) 100$ (ECa-electrical conductivity of distilled water, ECb-electrical conductivity at $45^{\circ} \mathrm{C}, \mathrm{ECc}-$ electrical conductivity at $100^{\circ} \mathrm{C}$ ).

Leaf membrane stability index (MSI) was determined according to the method of Premchandra et al., (1990) as modified by Sairam (1994). The MSI was calculated as: Membrane stability index $(\mathrm{MSI})=[1-(\mathrm{C} 1 /$ C2) $] \times 100$

The estimation of chlorophyll content was done by SPAD method (SPAD-502 plus). Fresh leaves were taken and cut into round discs. Readings in triplicate were taken with the help of SPAD. The ascorbic acid content was estimated titrimetrically, using 2,6dichlorophenol indophenols (2,6-DCPIP) dye, as per the method of (Rangana1977). Ascorbic acid content was calculated as ascorbic acid $\mathrm{mg} / 100 \mathrm{~g}$ leaf sample. The total carotenoids were extracted and partitioned in acetone and petroleum ether, as described by (Thimmaiah1999). Absorbance measured at $452 \mathrm{~nm}$ and total carotenoid content $(\mathrm{mg} / 100 \mathrm{~g})$ was calculated using a calibration curve prepared against a high purity $\beta$ carotene. Proline was extracted and estimated according to (Bates et al., 1973). $100 \mathrm{mg}$ of leaf tissues were homogenized in $2 \mathrm{ml}$ of $3 \%$ sulfosalicylic acid solution using tissue homogenizer. The homogenate was centrifuged at $13,000 \mathrm{~g}$ for 10 minutes. $1 \mathrm{ml}$ of the supernatant was then added into a test tube to which $1 \mathrm{ml}$ of glacial acetic acid and 1 $\mathrm{ml}$ of freshly prepared acid Ninhydrin solution were added. Tubes were incubated in 
a water bath for $1 \mathrm{~h}$ at $100^{\circ} \mathrm{C}$, allowed to cool to room temperature and then $2 \mathrm{ml}$ of toluene was added and vortexed for 20 seconds. The test tubes were allowed to stand for at least 10 minutes to allow the separation of toluene and aqueous phase. The absorbance of toluene phase was measured at $520 \mathrm{~nm}$ in a spectrophotometer. The concentration of proline was calculated from proline standard curve. The concentration of proline was expressed as $\mu \mathrm{mol} / \mathrm{g}$ FW. Reducing sugars other than starch were extracted from fresh leaf material according to the procedure of (Cerning and Guilhot, 1973). Total soluble sugars were determined spectrometrically using $0.2 \%$ anthrone in concentrated sulphuric acid as reagent following the method of (Yemm and Willis, 1954).

All the experimental data are the mean of five replicates. The mean values are shown with the critical difference (CD) in the tables and in the figures.

A Student's t-test was performed to determine significant differences between control and drought treatment and differences among genotypes under both conditions (irrigated as well as drought stress) were analysed by oneway analysis of variance (ANOVA). The dendogram representing agglomerative hierarchical clustering was constructed using UPGMA method. All these statistical analyses were done using Microsoft EXCEL 2007 software package (Microsoft Corp.; Redlands, WA, USA).

\section{Results and Discussion}

Present study investigated the morphological, physiological and biochemical performance of the fifteen tomato genotypes exposed to drought stress at growth stage (45 days) and irrigated plants were grown under non-stress conditions for the same period of time. Results showed that drought stress considerably reduced the growth of tomato genotypes in terms of plant height, number of branches, root length, shoot length, yield and their attributing characters as well as physiological traits. Drought stress unfavorably affects the meristematic activity, cell elongation, causes premature abscission of leaves and roots, reduces the accumulation of dry matter and the photosynthetic activity (Latif et al., 2016).

Plant height data ranged from $39.62 \mathrm{~cm}$ to $99.55 \mathrm{~cm}$ amongst the 15 tomato genotypes in irrigated condition (Table 2). The maximum plant height in irrigated condition was recorded in EC-317-6-1 $(99.55 \mathrm{~cm})$ followed by WIR-13706 and minimum was recorded in Money Maker (39.62 cm). EC-317-6-1 genotypes showed significantly higher value than other genotypes. Under drought stress condition, height varied from $22.61 \mathrm{~cm}$ to $54.51 \mathrm{~cm}$ amongst the tomato genotypes. The maximum plant height in drought stress condition was recorded in F-7012 $(54.51 \mathrm{~cm})$ followed by Roma and however, minimum plant height was recorded in Money Maker followed by C-26-1under drought stress condition. The genotypes Azad T-5, Roma, F7012, WIR-13706 are significantly at par. The results showed decreasing trend in drought stress as compared to irrigated condition (Fig. $1)$.

The number of branches ranged from $7.33 \mathrm{~cm}$ to $19.00 \mathrm{~cm}$ amongst 15 tomato genotypes in irrigated condition (Table 2). The maximum number of branches in irrigated condition was recorded in Kashi Amrit $(19.00 \mathrm{~cm})$ followed by EC-317-6-1 and minimum was recorded in Azad T-5 (7.33). EC-317-6-1 genotype showed significantly higher than other genotypes. Under drought stress condition, number of branches varied from 5.33-14.33 amongst the tomato genotypes. The maximum of branches in drought stress condition was recorded in Kashi Amrit (14.33) followed by 
Roma and EC-317-6-1 and minimum number of branches in drought condition was recorded in Azad T-5 (5.33) followed by VRT-32 and Kashi Sharad. The genotypes Kashi Anupam, WIR-13706 and Roma are significantly at par. The results showed decreasing trend in drought stress as compared to irrigated condition (Fig. 2).

The maximum root length was recorded in F7012 (13.36) in irrigated condition followed by VRT-32 and WIR-4360. The minimum root length was recorded in Kashi Sharad (3.45), followed by Money Maker, C-26-1 and F-7028 in irrigated condition. The maximum root length in drought stress condition was recorded in EC-317-6-1 (21.22), followed by VRT-32 and minimum root length in drought condition was recorded in C-26-1 (5.60) followed by Kashi Amrit and F-7012 and Kashi Sharad (Table 2). The results showed Increasing trend in drought stress as compared to irrigated condition (Fig. 3).

The maximum shoot length was recorded in EC-317-6-1 $(57.46 \mathrm{~cm})$ in irrigated condition followed by F-7028. The minimum root length was recorded in Money maker(29.96) in irrigated condition which is followed by VRT-32.Under drought stress shoot length varied from $18.60 \mathrm{~cm}-43.12 \mathrm{~cm}$. The maximum shoot length in drought condition was recorded in F-7028 (43.12) followed by Roma and Kashi Sharad. The minimum shoot length in drought condition was recorded in Money maker (18.60) followed by VRT-32 and Kashi Anupam (Table 2). The results showed decreasing trend in drought stress as compared to irrigated condition (Fig. 4).

The number of cluster/plant ranged from 2.00-12.67 amongst the 15 tomato genotypes in irrigated condition. The maximum number of cluster /plant in irrigated condition was recorded in EC-317-6-1 (12.67) followed by
Swaran Naveen and minimum was recorded in Kashi Amrit (2.00). EC-316-6-1 genotypes showed significantly higher than other genotypes. Under drought stress condition, number of cluster /plant varied from 1.008.67amongst the tomato genotypes The maximum number of cluster /plant in drought stress condition was recorded in EC-317-6-1 (8.67) followed by Swaran Naveen and minimum number of cluster/plant in drought condition was recorded in Kashi Amrit (1.00) followed by VRT-32 under drought stress. The genotypes Swaran Naveen and Kashi Anupam are significantly at par (Table 3). The results showed decreasing trend in drought stress as compared to irrigated condition (Fig. 5).

The maximum Number of flower/cluster in irrigated condition was recorded in Azad T-5 (7.33), followed by VRT-32 and minimum was recorded in F-7012 (4.33). Under drought stress condition, number of flower/cluster varied from 2.00-4.33. amongst the tomato genotypes. The maximum number of flower/cluster in drought stress condition was recorded in Money Maker (4.33) followed by Azad T-5 and minimum number of flower/cluster in drought condition was recorded in F-7012(1.00) followed by VRT32 under drought stress. The genotypes Swaran Naveen and VRT-32 are significantly at par (Table 3). The results showed decreasing trend in drought stress as compared to irrigated condition (Fig. 6).

The maximum number of flowers per plant in irrigated condition was recorded in EC-317-61(61.00) followed by WIR-4360 and minimum was recorded in C-26-1(10.67). EC317-6-1 genotype showed significantly higher number of flowers per plant than other genotypes under irrigated conditions. Under drought stress condition number of flower per plant varied from (10.00-51.00) amongst the tomato genotypes. The maximum number of 
flower per plant in drought stress condition was recorded in EC-317-6-1 (51.00) followed by Kashi Anupam and minimum number of flower per plant in drought condition was recorded in C-26-1(10.00) followed by Kashi Amrit under drought stress (Table 3). The results showed decreasing trend in drought stress as compared to irrigated condition (Fig. 7).

The maximum number of fruits per plant was recorded in Money Maker (12.33) and minimum was recorded in Kashi Sharad (2.33). Under drought stress, range varied from 1.00-5.67 (Table 3). The maximum number of fruits per plant was recorded in Money Maker (5.67) and minimum number of fruits per plant was recorded in Kashi Sharad (1.00) in drought stress conditions. The results showed decreasing trend in drought stress as compared to irrigated condition (Fig. 8).

The Fruit setting (\%) ranged from 7.01-48.14 amongst the 15 tomato genotypes in control condition and in drought condition 2.8643.85. The maximum Fruit setting (\%) was recorded in Money Maker in both the conditions. The minimum Fruit setting (\%) was recorded in Kashi Sharad (7.01) in control condition and in drought condition in KashiAnupam (2.86) (Table 3).The results showed decreasing trend in drought stress as compared to irrigated condition (Fig. 9).

The Ratio of Root length/Shoot length ranged from 0.16-0.54 amongst the 15 tomato genotypes in irrigated condition. The maximum Ratio of Root length/Shoot length was recorded in VRT-32 (0.542) in irrigated condition followed by WIR-4360. The minimum Ratio of Root length/Shoot length was recorded in C-26-1 (0.16) in control condition. Under drought stress condition range varied from $0.07-0.41$. The maximum ratio of Root length/Shoot length in drought condition was recorded in WIR-4360 (0.41). The minimum Ratio of Root length/Shoot length was recorded in F-7028(0.07) followed by C-26-1 (Table 3). The results showed decreasing trend in drought stress as compared to irrigated condition (Fig. 10).

The Leaf Area $\left(\mathrm{cm}^{2}\right)$ ranged from 67.30204.75 amongst the 15 tomato genotypes in irrigated condition. Under drought stress, leaf area varied from 60.88-152.60. The maximum Leaf Area $\left(\mathrm{cm}^{2}\right)$ was recorded in Kashi Sharad in both the conditions followed by Kashi Amrit and Kashi Anupam and the minimum Leaf Area $\left(\mathrm{cm}^{2}\right)$ was recorded in EC-317-6-1 in both the conditions followed by Kashi Anupam. The genotypes Swaran Naveen, Money Maker and VRT-32 are statistically at par (Table 3). The results showed decreasing trend in drought stress as compared to irrigated condition (Fig. 11).

The maximum Relative water content (\%) was recorded in F-7028 (95.43) in irrigated condition followed by Azad T-5. The minimum Relative water content (\%) was recorded in Kashi Amrit (52.11) in control condition followed by F-7012. Under drought stress range varied from 47.43-74.83 (Table $3)$. The maximum Relative water content (\%) was recorded in Kashi Amrit (74.83) in drought condition followed by Swaran Naveen. The minimum relative water content (\%) was recorded in drought condition in WIR-4360 (47.43) genotypes followed by F7012 (Fig. 12).

The maximum Electrolyte Leakage (\% conductivity) was recorded in Kashi Amrit (96.83) in irrigated condition followed by F7012. The minimum Electrolyte Leakage (\% conductivity) was recorded in WIR4360(73.64) in irrigated condition followed by Money Maker. Under drought condition range varied from 75.78-94.69. The maximum Electrolyte Leakage $(\%$ 
conductivity) was recorded in WIR-4360 (94.69) in drought condition followed by WIR-13706. The minimum Electrolyte Leakage ( $\%$ conductivity) was recorded in drought condition in C-26-1(75.78) followed by F-7028 (Table 3). The results showed decreasing trend in drought stress as compared to irrigated condition (Fig. 13).

Titrimetric analysis of ascorbic acid showed significant variation in vitamin-C levels estimated in freshly harvested fruits of 15 tomato genotypes. In this study, the vitamin-C concentration ranged from (14.94$32.54 \mathrm{mg} / 100 \mathrm{~g}$ ) in irrigated condition and in drought condition (15.66-25.51 mg/100g). The maximum ascorbic acid content was recorded in F-7028 (32.54 $\mathrm{mg} / 100 \mathrm{~g})$ in irrigated condition and in Money Maker (25.51 mg/100g) in drought condition. The minimum ascorbic acid content was recorded in WIR-13706 (14.91 mg/100g) in irrigated condition and in drought condition in Kashi Sharad (15.66 mg/100g) (Table 4). The results showed increasing trend in drought stress as compared to irrigated condition (Fig. 14).

Maximum carotenoid content was recorded in Swaran Naveen $(8.92 \mathrm{mg} / 100 \mathrm{~g})$ in irrigated condition and in drought condition in EC317-6-1 (3.04 mg/100g) respectively. The minimum total carotenoids content was noted in F-7028 (3.42mg/100g) in irrigated condition and in drought condition in WIR$4360(0.58 \mathrm{mg} / 100 \mathrm{~g})$ (Table 4$)$. The results showed increasing trend in drought stress as compared to irrigated condition (Fig.15).

Maximum Total Chlorophyll content was recorded in Azad T-5 (57.36) in irrigated condition and in Kashi Anupam (49.73) in drought condition respectively. The minimum Total Chlorophyll content was noted in Swaran Naveen (23.38) in control condition and in drought condition in Kashi Sharad (10.11) (Table 4). The results showed decreasing trend in drought stress as compared to irrigated condition (Fig. 16).

Proline level was increased significantly $(\mathrm{P} \leq$ 0.05) in all genotypes under drought. Significant variation was recorded in the Total Chlorophyll content amongst the 15 tomato genotypes. Under drought stress, WIR-4360 showed increase in proline level as compared to control. Minimum increase was found in Roma as compared to control (Table 5). The results showed increasing trend in drought stress as compared to irrigated condition (Fig. 17).

Sugar level was increased significantly $(\mathrm{P} \leq$ 0.01 and 0.05 ) in all genotypes under drought. Significant variation was recorded in the Total Chlorophyll content amongst the 15 tomato genotypes. Under drought stress condition, Roma showed increase in Sugar level as compared to control. Minimum increase was found in Kashi Amrit compared to control (Table 5). The results showed increasing trend in drought stress as compared to irrigated condition (Fig. 18). Descriptive statistics for plant growth parameters in 15 tomato genotypes under drought stress is given in Table 6.

Based on the above investigation of morphological characters, yield attributing characters, physiological characters, antioxidant phytochemicals and osmolytes, the hierarchical cluster was formed which distinguished the 15 genotypes and were classified into 2 groups, one cluster contain only cultivated genotypes and another cluster contain other 12 mixed wild and cultivated genotypes. Now from the 2 clusters, 2 wild and 2 other genotypes were selected for the Antioxidant isozymes (Fig. 19). 
Table.1 List of tomato genotypes used in the study along with their source

\begin{tabular}{|c|c|c|}
\hline S.No. & Genotypes & Source \\
\hline 1. & Azad T-5 (Solanum lycopersicum L.) & IIVR, Varanasi \\
\hline 2. & Kashi Sharad (Solanum lycopersicum) & IIVR, Varanasi \\
\hline 3. & Roma (Solanum lycopersicum) & IIVR, Varanasi \\
\hline 4. & Kashi Amrit (Solanum lycopersicum) & IIVR, Varanasi \\
\hline 5. & EC-317-6-1 (Solanum lycopersicum) & IIVR, Varanasi \\
\hline 6. & Hisar Arun (Solanum lycopersicum) & IIVR, Varanasi \\
\hline 7. & Swaran Naveen (Solanum lycopersicum) & IIVR, Varanasi \\
\hline 8. & Money Maker (Solanum lycopersicum) & IIVR, Varanasi \\
\hline 9. & WIR-4360 (Solanum peruvianum) & IIVR, Varanasi \\
\hline 10. & VRT-32 (Solanum lycopersicum) & IIVR, Varanasi \\
\hline 11. & F-7012 (Solanum lycopersicum) & IIVR, Varanasi \\
\hline 12. & WIR-13706 (Solanum L. ceresiforme) & IIVR, Varanasi \\
\hline 13. & Kashi Anupam (Solanum lycopersicum) & IIVR, Varanasi \\
\hline 14. & C-26-1 (Solanum lycopersicum) & IIVR, Varanasi \\
\hline 15. & F-7028 (Solanum lycopersicum) & IIVR, Varanasi \\
\hline
\end{tabular}


Table. 2 Changes in morphological parameters of fifteen tomato genotypes exposed to drought stress $(\mathrm{N}=$ normal condition, $\mathrm{D}=$ drought condition $)$

\begin{tabular}{|c|c|c|c|c|c|c|c|c|}
\hline \multirow[t]{2}{*}{ Genotypes } & \multicolumn{2}{|c|}{ Plant height (cm) } & \multicolumn{2}{|c|}{ Root length (cm) } & \multicolumn{2}{|c|}{ Shoot length (cm) } & \multicolumn{2}{|c|}{ No. of branches } \\
\hline & $\mathbf{N}$ & $\mathbf{N}$ & D & D & $\mathbf{N}$ & & & \\
\hline & 65.53 & 38.35 & 4.54 & 14.56 & 50.64 & 33.75 & 7.33 & 5.33 \\
\hline Azad T-5 & 51.09 & 43.59 & 3.45 & 7.30 & 43.67 & 40.14 & 12.33 & 6.67 \\
\hline Kashi Sharad & 70.11 & 51.04 & 9.39 & 17.42 & 52.85 & 41.65 & 16.33 & 11.33 \\
\hline Roma & 49.24 & 41.34 & 6.28 & 6.98 & 38.85 & 35.05 & 19.00 & 14.33 \\
\hline Kashi Amrit & 99.55 & 48.52 & 8.69 & 21.17 & 57.46 & 36.32 & 18.33 & 11.33 \\
\hline EC-317-6-1 & 44.69 & 42.32 & 8.66 & 9.01 & 43.67 & 31.55 & 11.67 & 7.67 \\
\hline HisarArun & 51.82 & 43.67 & 10.65 & 12.94 & 48.62 & 34.78 & 13.00 & 12.67 \\
\hline SwaranNaveen & 39.62 & 22.61 & 3.64 & 9.48 & 29.96 & 18.60 & 14.33 & 9.33 \\
\hline Money Maker & 50.67 & 38.62 & 11.20 & 16.13 & 34.54 & 27.43 & 11.00 & 7.00 \\
\hline WIR-4360 & 53.49 & 42.92 & 11.26 & 18.26 & 33.72 & 28.71 & 11.00 & 6.00 \\
\hline VRT-32 & 71.34 & 50.03 & 13.36 & 7.30 & 42.32 & 36.48 & 12.00 & 10.00 \\
\hline F-7012 & 68.06 & 47.68 & 9.48 & 12.22 & 51.68 & 37.61 & 16.00 & 12.67 \\
\hline WIR-13706 & 44.71 & 40.08 & 9.55 & 10.50 & 34.03 & 31.48 & 15.00 & 10.00 \\
\hline Kashi Anupam & 43.67 & 40.87 & 3.56 & 5.60 & 40.15 & 35.04 & 11.33 & 7.00 \\
\hline C-26-1 & 57.22 & 54.51 & 3.62 & 10.73 & 53.37 & 43.12 & 11.33 & 9.00 \\
\hline F-7028 & $39.62-$ & $22.61-$ & $3.45-$ & $5.60-$ & 29.96- & $18.60-$ & $7.33-$ & $5.33-$ \\
\hline \multirow[t]{2}{*}{ Range } & 99.55 & 51.04 & 13.36 & 21.17 & 57.46 & 43.12 & 19.00 & 14.33 \\
\hline & 9.38 & 9.31 & 2.25 & 6.65 & 8.75 & 9.02 & 3.48 & 3.66 \\
\hline C.D@5\% & & & & & & & & \\
\hline
\end{tabular}


Table.3 Changes in yield attributing parameters of fifteen tomato genotypes exposed to drought stress $(\mathrm{N}=$ normal condition, $\mathrm{D}=$ drought condition $)$

\begin{tabular}{|c|c|c|c|c|c|c|c|c|c|c|}
\hline Genotypes & usters /p & lant & ower /cl & ster Flc & wers /pl & $\operatorname{nt}(\mathrm{N})$ & Fruit/PI & nt & uit sett & \\
\hline & $\mathbf{N}$ & D & $\mathbf{N}$ & D & 1 & $\mathrm{I}$ & D & $\mathbf{N}$ & D & \\
\hline Azad T-5 & 5.67 & 2.337 & 3.6 & 43.00 & 34.67 & 5.33 & 2.001 & 51 & & \\
\hline Kashi Sharad & .33 & 6.006 & 3.00 & 33.33 & 27.67 & 2.33 & 1.00 & 01 & & \\
\hline Roma & 5.00 & 3.00 & $\begin{array}{ll}0 & 2.6\end{array}$ & 26.00 & 15.33 & 2.67 & 2 & 59 & & \\
\hline Kashi Amrit & 2.00 & 1.00 & 4.67 & 2.67 & 15.33 & 10.33 & 4.00 & 3.00 & 39.09 & 20.73 \\
\hline EC-317-6-1 & 12.67 & 8.67 & 4.67 & 3.00 & 61.00 & 51.00 & 11.00 & 3.00 & 18.08 & 5.89 \\
\hline Hisar Arun & 3.67 & 2.00 & 5.33 & 2.33 & 20.67 & 13.67 & 4.00 & 2.67 & 32.47 & 12.27 \\
\hline Swaran Naveen & 8.00 & 8.00 & 6.33 & 2.67 & 38.67 & 33.67 & 9.00 & 1.67 & 23.33 & 5.69 \\
\hline Money Maker & 6.00 & 4.00 & 5.33 & 4.33 & 25.67 & 14.00 & 12.33 & 5.67 & 48.14 & 43.85 \\
\hline WIR-4360 & 7.00 & 3.00 & 6.33 & 2.00 & 47.00 & 33.67 & 5.00 & 1.00 & 10.64 & 2.97 \\
\hline VRT-32 & 4.67 & 2.00 & 6.67 & 3.00 & 32.00 & 26.33 & 3.00 & 2.67 & 13.44 & 11.36 \\
\hline F-7012 & 6.33 & 3.33 & 4.33 & 2.00 & 24.00 & 13.33 & 3.67 & 2.33 & 15.46 & 14.91 \\
\hline WIR-13706 & 6.00 & 3.00 & 6.00 & 3.00 & 28.67 & 18.67 & 4.00 & 2.33 & 14.05 & 13.21 \\
\hline KashiAnupam & 7.33 & 7.33 & 5.67 & 2.00 & 38.67 & 36.33 & 3.33 & 1.33 & 8.86 & 2.86 \\
\hline C-26-1 & 2.00 & 2.00 & 6.33 & 2.67 & 10.67 & 10.00 & 4.33 & 1.67 & 41.11 & 20.00 \\
\hline F-7028 & 4.00 & 2.00 & 6.67 & 3.33 & 24.67 & 15.33 & 4.33 & 1.67 & 17.55 & 6.55 \\
\hline Range & $\begin{array}{l}2.00- \\
12.67\end{array}$ & $\begin{array}{l}1.00- \\
8.67\end{array}$ & $\begin{array}{l}4.33- \\
7.33\end{array}$ & $\begin{array}{c}2.00- \\
4.33\end{array}$ & $\begin{array}{c}10.67- \\
61.00\end{array}$ & $\begin{array}{l}10.00 \\
51.00\end{array}$ & $\begin{array}{l}2.33- \\
12.33\end{array}$ & $\begin{array}{r}1.00- \\
5.67\end{array}$ & $\begin{array}{l}7.01- \\
48.14\end{array}$ & $\begin{array}{l}2.86- \\
43.85\end{array}$ \\
\hline C.D@5\% & 1.13 & 1.28 & 2.15 & 1.44 & 5.26 & 6.87 & 1.18 & 1.93 & 10.80 & 10.86 \\
\hline
\end{tabular}


Table.4 Changes in Physiological characters parameters of fifteen tomato genotypes exposed to drought stress $(\mathrm{N}=$ normal condition, $\mathrm{D}=$ drought condition)

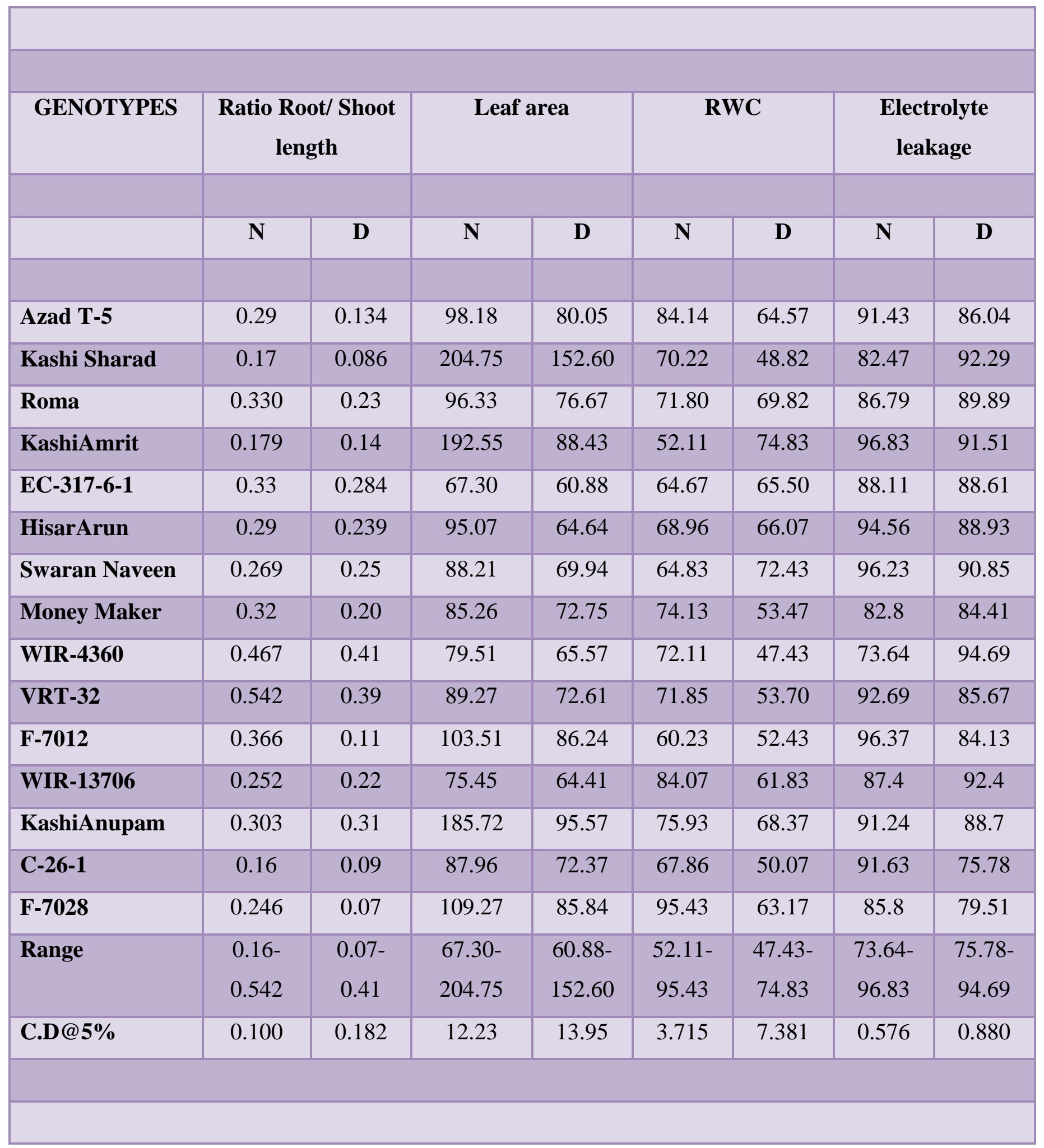


Table.5 Changes in Antioxidant phytochemicals and osmolytes of fifteen tomato genotypes exposed to drought stress ( $\mathrm{N}=$ normal condition, $\mathrm{D}=$ drought condition)

\begin{tabular}{|c|c|c|c|c|c|c|c|c|c|c|}
\hline \multirow[t]{2}{*}{ Genotypes } & \multicolumn{2}{|c|}{ Ascorbic Acid } & \multicolumn{2}{|c|}{$\begin{array}{c}\text { Chlorophyll } \\
\text { content }\end{array}$} & \multicolumn{2}{|c|}{$\begin{array}{l}\text { Carotenoid( } \\
\mathrm{mg} / \mathbf{1 0 0 g})\end{array}$} & \multicolumn{2}{|c|}{$\begin{array}{c}\text { Proline ( } \mu \mathrm{mol} \\
\mathrm{g}^{-1} \text { of fresh } \\
\text { leaf wt.) }\end{array}$} & \multicolumn{2}{|c|}{$\begin{array}{l}\text { Reducing Sugar } \\
\text { content (mg/g of } \\
\text { fresh wt.) }\end{array}$} \\
\hline & $\mathbf{N}$ & D & $\mathbf{N}$ & D & $\mathbf{N}$ & D & $\mathbf{N}$ & D & $\mathbf{N}$ & D \\
\hline Azad T-5 & 18.41 & 17.67 & 57.36 & 26.35 & 7.57 & 0.97 & 11.34 & 12.21 & 16.34 & 19.74 \\
\hline Kashi Sharad & 18.60 & 15.66 & 25.47 & 10.11 & 4.67 & 2.58 & 9.04 & 10.43 & 15.98 & 18.17 \\
\hline Roma & 22.14 & 20.10 & 53.80 & 46.51 & 7.92 & 2.64 & 4.94 & 6.32 & 16.56 & 20.89 \\
\hline Kashi Amrit & 25.48 & 22.51 & 47.93 & 42.25 & 8.54 & 2.73 & 6.38 & 7.14 & 16.68 & 16.57 \\
\hline EC-317-6-1 & 27.33 & 25.12 & 53.40 & 45.37 & 6.83 & 3.04 & 4.46 & 8.85 & 16.82 & 20.36 \\
\hline Hisar Arun & 23.53 & 15.71 & 26.47 & 17.14 & 7.9 & 1.83 & 8.08 & 10.43 & 15.86 & 17.93 \\
\hline Swaran Naveen & 21.56 & 19.49 & 23.38 & 15.11 & 8.92 & 1.85 & 11.33 & 12.43 & 16.69 & 18.42 \\
\hline Money Maker & 25.48 & 25.51 & 45.33 & 40.72 & 8.82 & 0.81 & 7.05 & 9.75 & 14.92 & 18.28 \\
\hline WIR-4360 & 24.78 & 19.13 & 51.46 & 47.52 & 6.73 & 0.58 & 10.02 & 12.85 & 15.38 & 19.58 \\
\hline VRT-32 & 27.26 & 21.74 & 56.40 & 39.48 & 5.21 & 1.83 & 5.09 & 8.65 & 16.83 & 17.42 \\
\hline F-7012 & 23.20 & 23.88 & 39.27 & 23.45 & 8.73 & 1.74 & 8.88 & 9.75 & 15.48 & 19.81 \\
\hline WIR-13706 & 14.94 & 21.76 & 39.60 & 34.62 & 5.34 & 1.89 & 6.32 & 8.79 & 16.18 & 18.59 \\
\hline Kashi Anupam & 23.54 & 20.15 & 54.57 & 49.73 & 7.62 & 3.01 & 7.89 & 8.23 & 16.94 & 17.85 \\
\hline C-26-1 & 26.27 & 23.74 & 46.50 & 39.76 & 8.29 & 2.39 & 7.7 & 11.97 & 14.27 & 19.36 \\
\hline F-7028 & 32.54 & 23.39 & 40.53 & 27.17 & 3.42 & 2.91 & 7.79 & 10.34 & 15.48 & 19.62 \\
\hline Range & $\begin{array}{l}14.94- \\
32.54\end{array}$ & $\begin{array}{l}15.66- \\
25.51\end{array}$ & $\begin{array}{r}23.38 \\
57.36\end{array}$ & $\begin{array}{l}10.11 \\
49.73\end{array}$ & $\begin{array}{l}3.42- \\
8.92\end{array}$ & $\begin{array}{l}0.58- \\
3.04\end{array}$ & $\begin{array}{l}4.46- \\
11.34\end{array}$ & $\begin{array}{l}6.32- \\
12.85\end{array}$ & $\begin{array}{r}14.27- \\
16.94\end{array}$ & $\begin{array}{l}16.57 \\
20.89\end{array}$ \\
\hline C.D@5\% & 1.99 & 3.515 & 3.47 & 3.924 & 0.880 & 0.574 & 1.64 & 3.23 & 3.41 & 3.94 \\
\hline
\end{tabular}


Table.6 Descriptive statistics for plant growth parameters in 15 tomato genotypes under drought stress $(\mathrm{N}=$ normal condition, $\mathrm{D}=$ drought condition $)$

\begin{tabular}{|l|c|c|c|}
\hline & Minimum value & Maximum value & Mean \\
\hline Parameters & 32.51 & 78.49 & 50.53 \\
\hline Plant Height(N)(cm) & 2.54 & 23.31 & 10.45 \\
\hline Plant Height(D)(cm) & 2.54 & 22.86 & 9.29 \\
\hline Root length(N)(cm) & 12.19 & 84.58 & 39.46 \\
\hline Root length(D)(cm) & 21.34 & 67.82 & 40.86 \\
\hline Shoot length(N)(cm) & 0.06 & 0.63 & 0.27 \\
\hline Shoot length(D)(cm) & 0.05 & 0.56 & 0.24 \\
\hline Ratio R/S(N)(cm) & 6.0 & 21.0 & 13.33 \\
\hline Ratio R/S(D)(cm) & 2.0 & 17.0 & 9.36 \\
\hline Number of branches(N) & 3.0 & 9.0 & 5.80 \\
\hline Number of branches(D) & 1.0 & 5.0 & 2.82 \\
\hline Clusters per plant(N) & 1.0 & 5.0 & 2.82 \\
\hline Clusters per plant(D) & 1.0 & 9.0 & 3.84 \\
\hline Flowers per plant(N) & 10.0 & 63.0 & 30.49 \\
\hline Flowers per plant(D) & 10.0 & 54.0 & 24.40 \\
\hline Flowers per cluster(N) & 2.0 & 13.0 & 5.18 \\
\hline Flowers per cluster(D) & 1.0 & 7.0 & 2.31 \\
\hline Fruits per plant(N) & 5.55 & 50.0 & 20.63 \\
\hline Fruits per plant(D) & 2.17 & 58.33 & 12.50 \\
\hline Fruit setting (\%)(N) & 14.79 & 32.98 & 23.67 \\
\hline Fruit setting(\%)(D) $(\mathbf{D})$ & 12.82 & 27.31 & 21.04 \\
\hline Ascorbic Acid(mg/100g)(N) & 22.0 & 59.54 & 44.10 \\
\hline Ascorbic Acid(mg/100g)(D) & 7.7 & 52.3 & 33.69 \\
\hline Chlorophyll content(N)ug /cm2 & 51.0 & 96.58 & 71.89 \\
\hline Chlorophyll content(D)ug /cm2 & 42.9 & 76.75 & 60.83 \\
\hline Relative water content Percentage(N) & 65.0 & 224.86 & 110.56 \\
\hline Relative water content Percentage (D) & 67.30 & 204.75 & 1.10 \\
\hline Leaf Area (cm)(N) & 60.88 & 152.60 & 80.57 \\
\hline Leaf Area(cm)(D) & 73.64 & 96.83 & 89.19 \\
\hline Percent conductivity(N) & 75.78 & 94.69 & 87.56 \\
\hline Percent conductivity(D) & 3.42 & 8.92 & 7.100 \\
\hline Total Carotenoid (mg/100g)(N) & .58 & 3.04 & 2.053 \\
\hline Total Carotenoid (mg/100g)(D) & & & \\
\hline & & & \\
\hline
\end{tabular}


Fig.1 Plant height of tomato genotypes

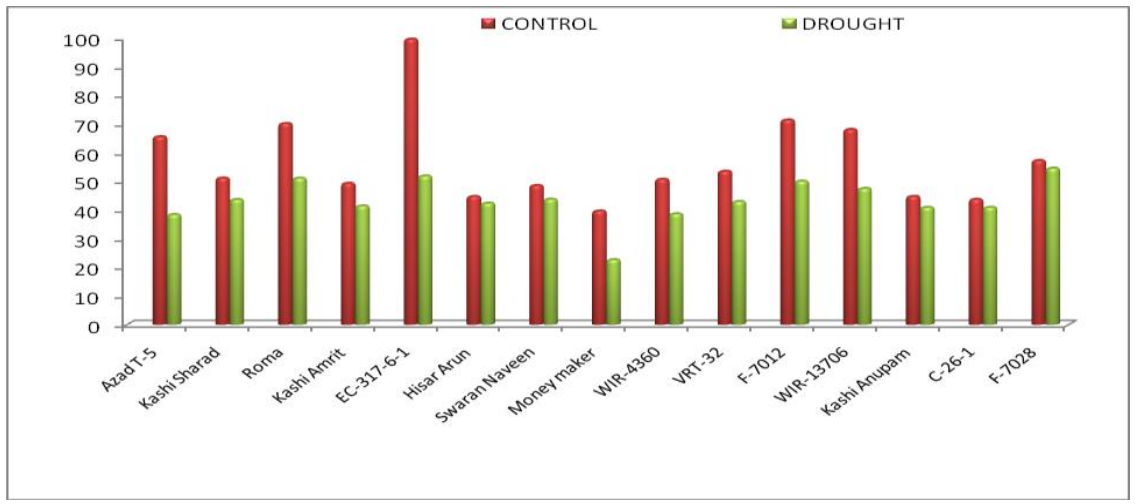

Fig.2 Number of branches of tomato genotypes

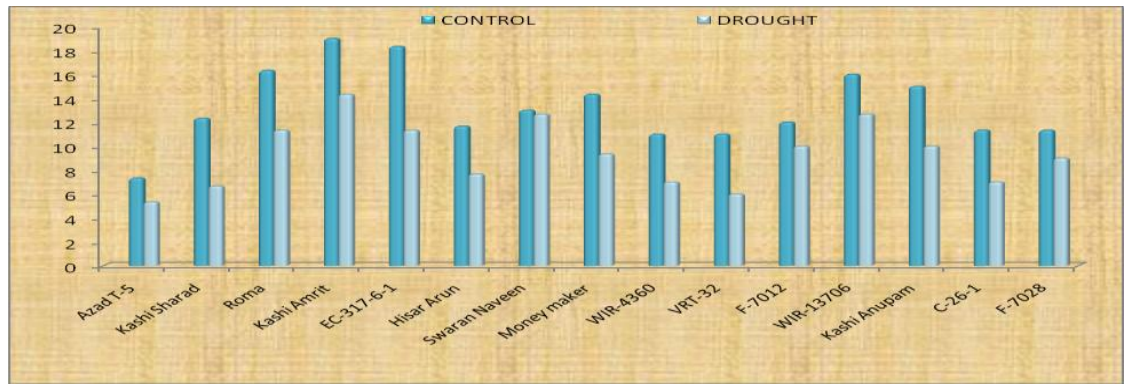

Fig.3 Root length of tomato genotypes

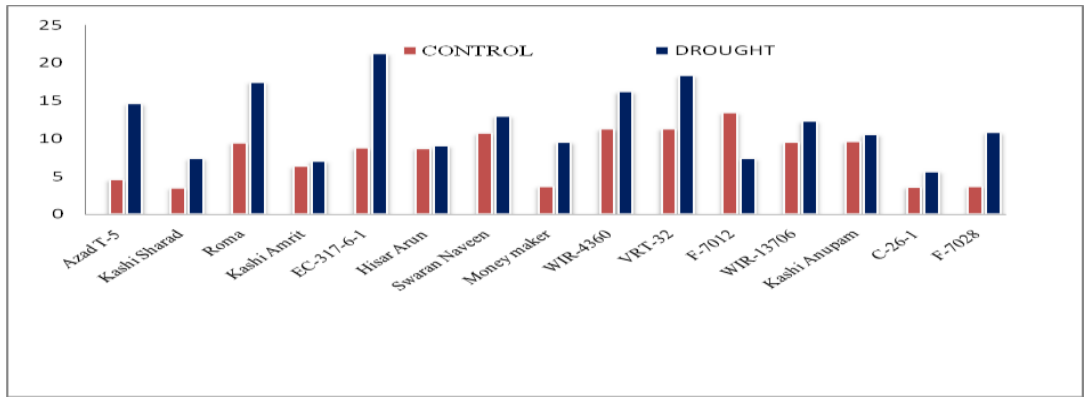

Fig.4 Shoot length of Tomato genotypes

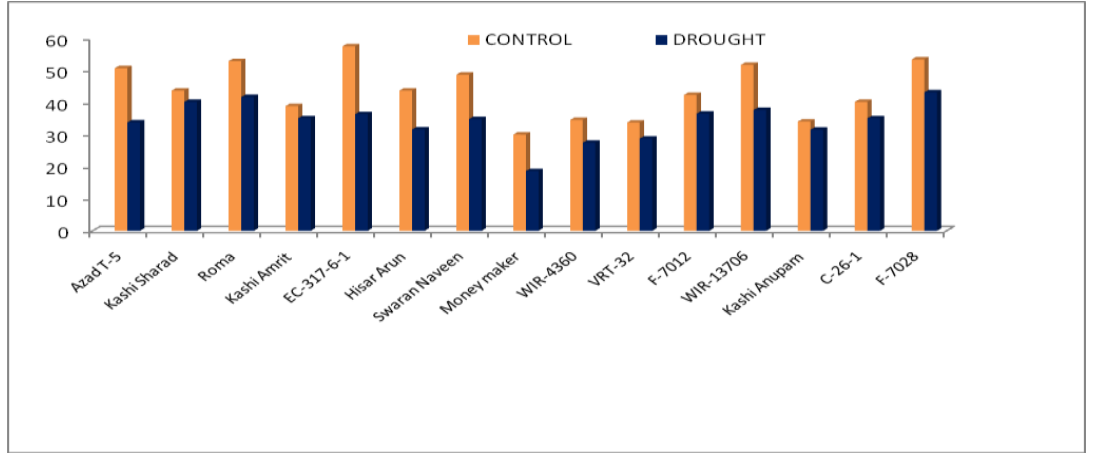


Fig.5 Number of cluster/Plant of tomato genotypes

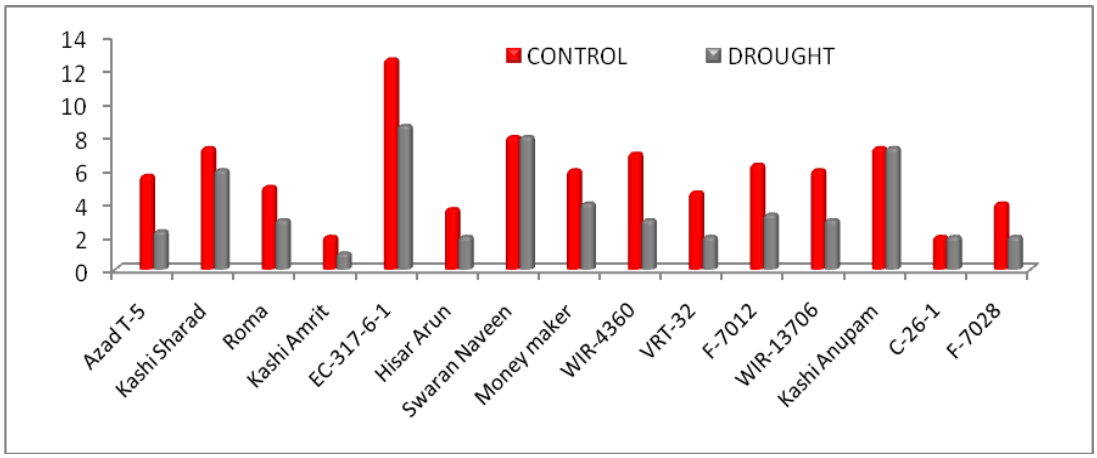

Fig.6 Number of Flower/cluster of tomato genotypes

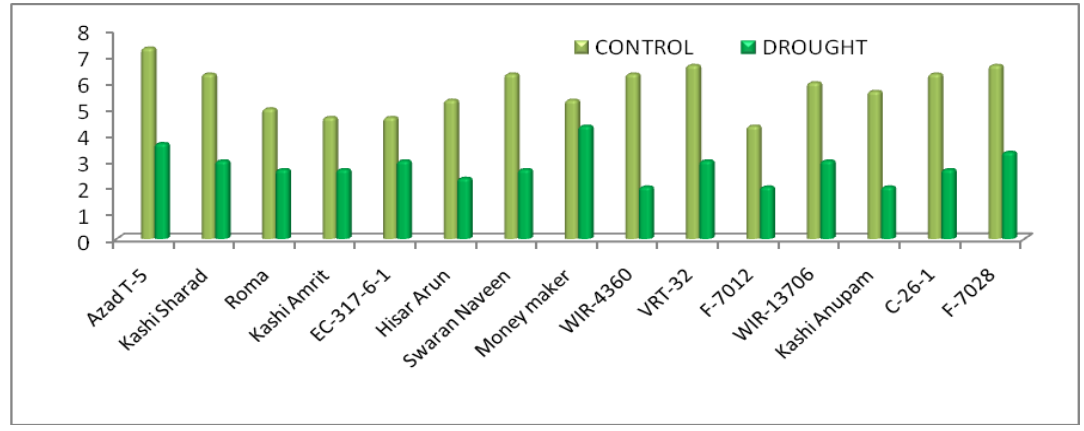

Fig.7 Number of Flower/plant of tomato

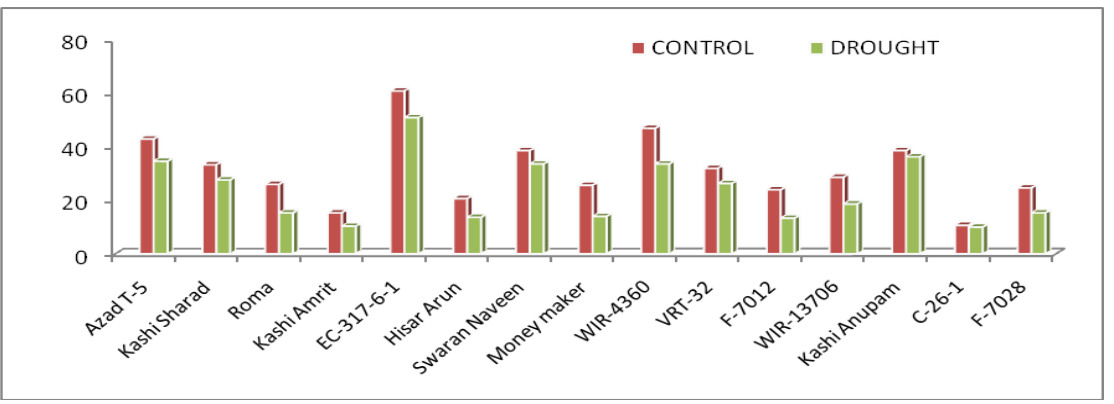

Fig.8 Number of Fruits/plant of tomato genotypes

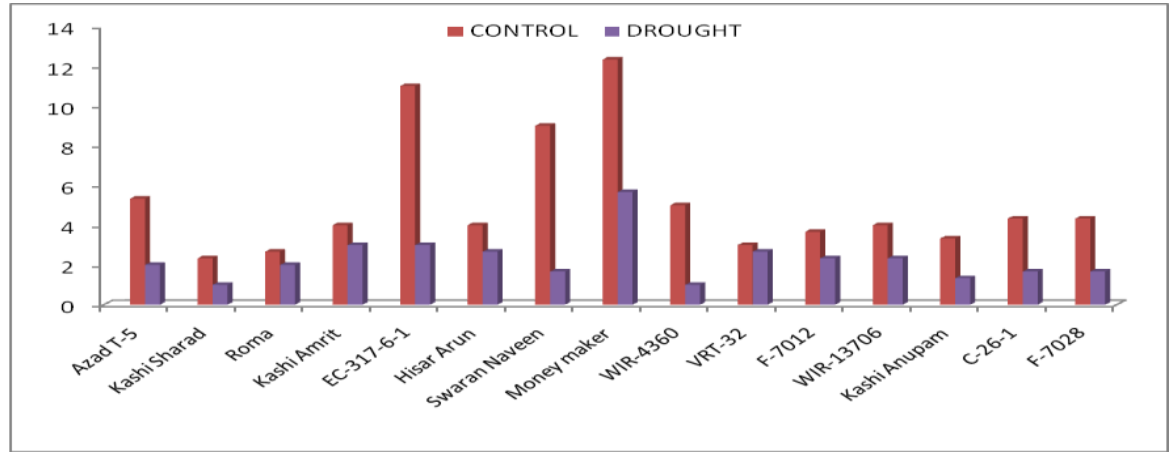


Fig.9 Fruit setting percent of tomato genotypes

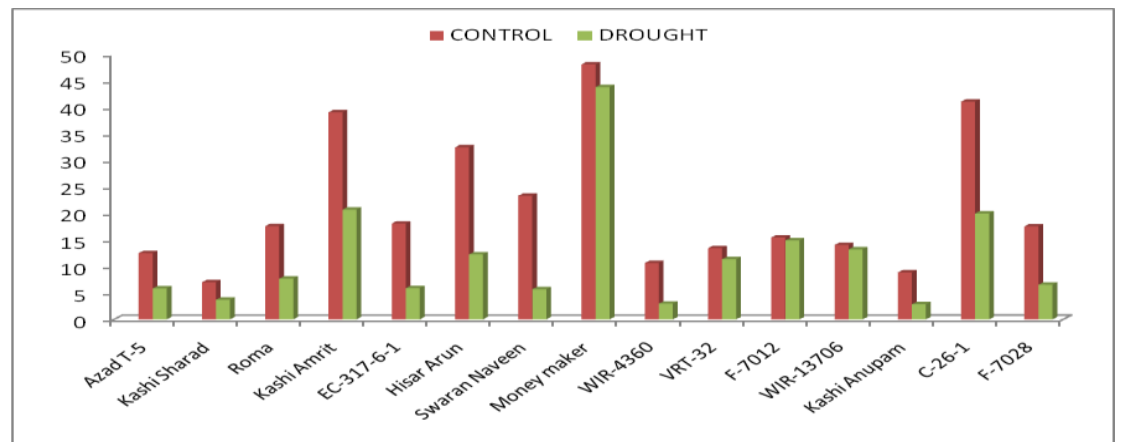

Fig.10 Ratio root length /shoot length of tomato genotypes

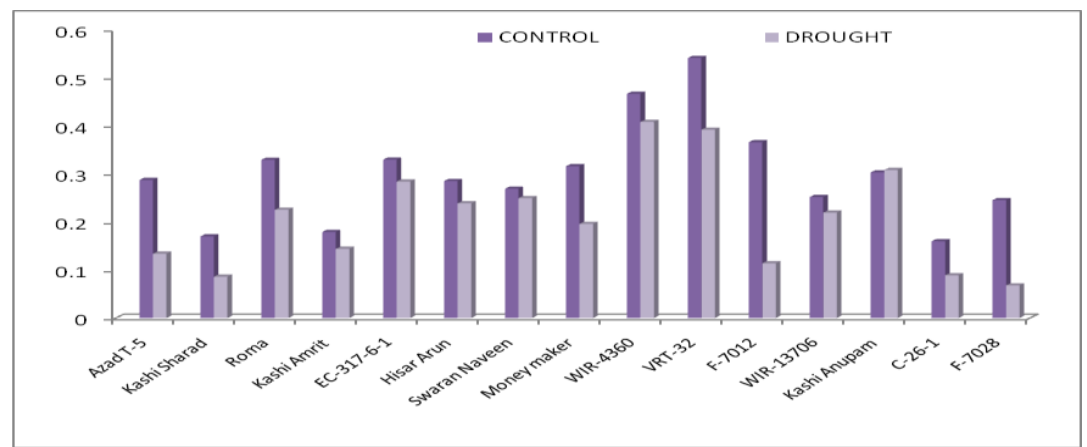

Fig.11 Leaf area of tomato genotypes

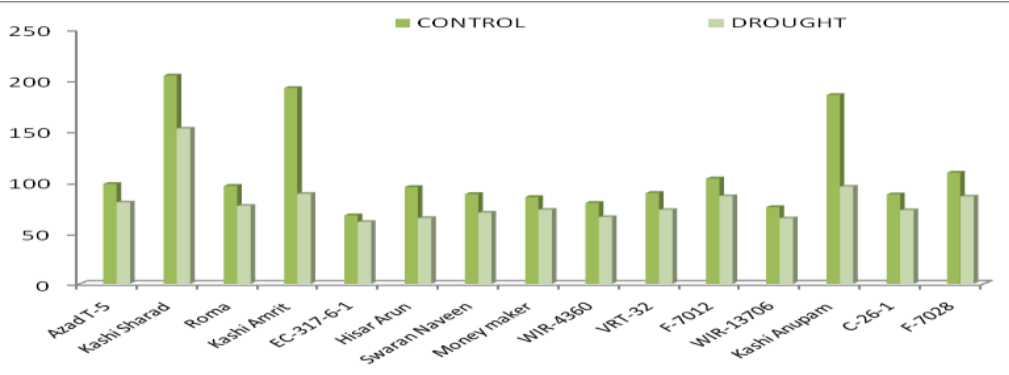

Fig.12 Relative water content (\%) of tomato genotypes

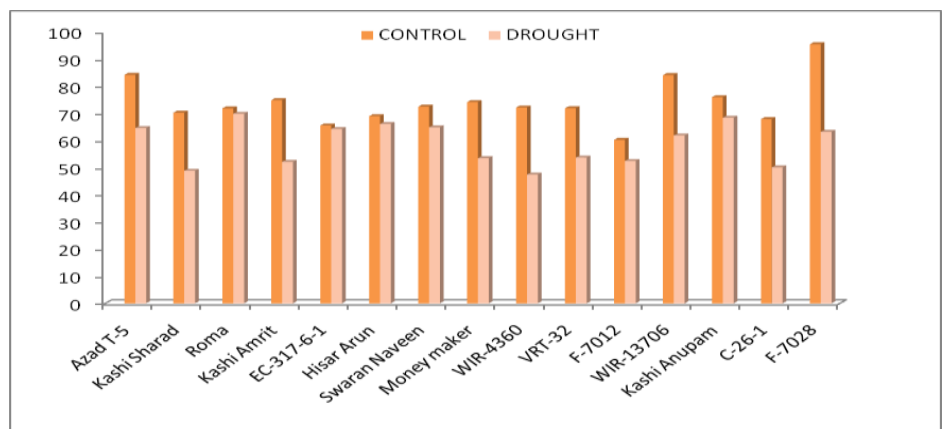


Fig.13 Electrolyte leakage of tomato genotypes

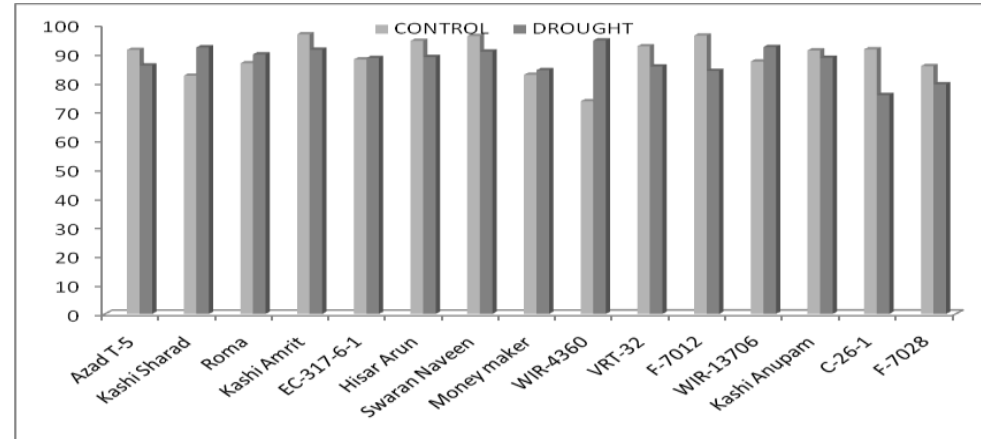

Fig.14 Ascorbic acid content of tomato genotypes

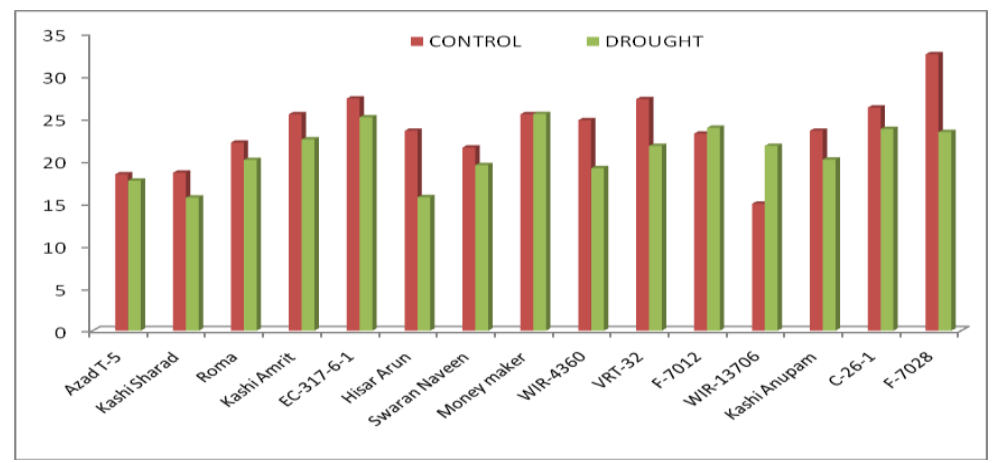

Fig.15 Carotenoid content of tomato genotypes

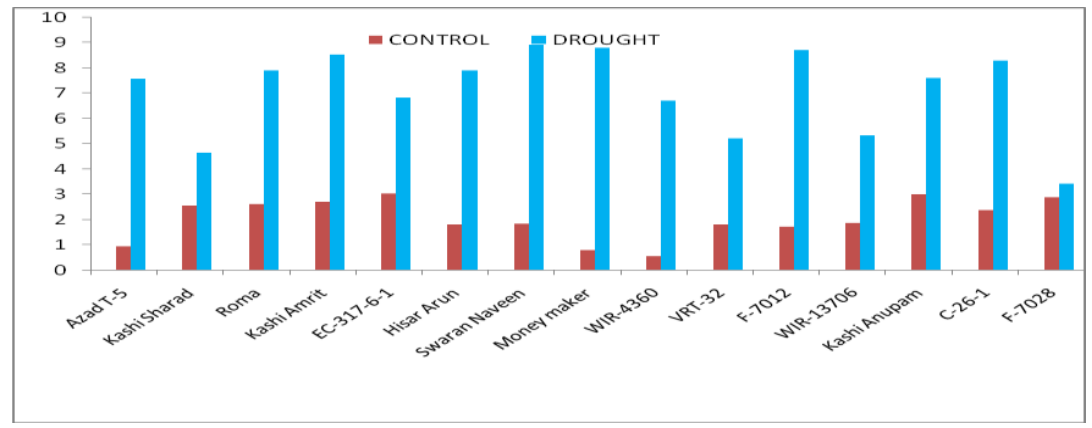

Fig.16 Chlorophyll content of tomato genotypes

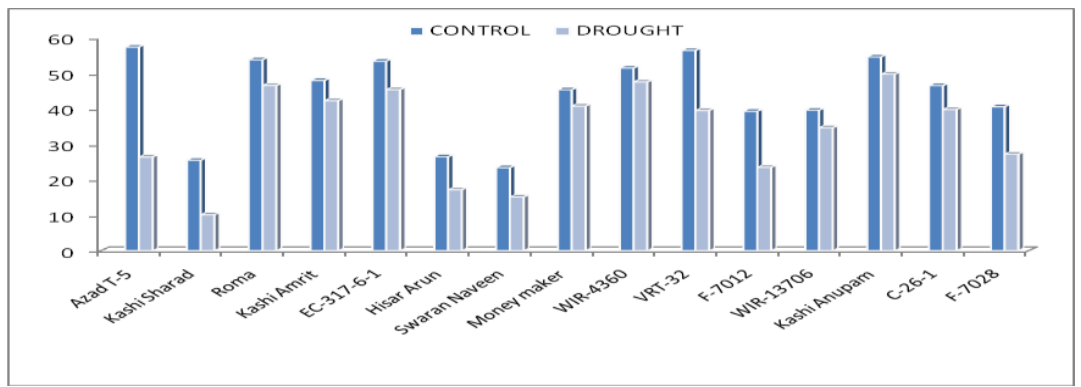


Fig.17 Proline content of tomato genotypes

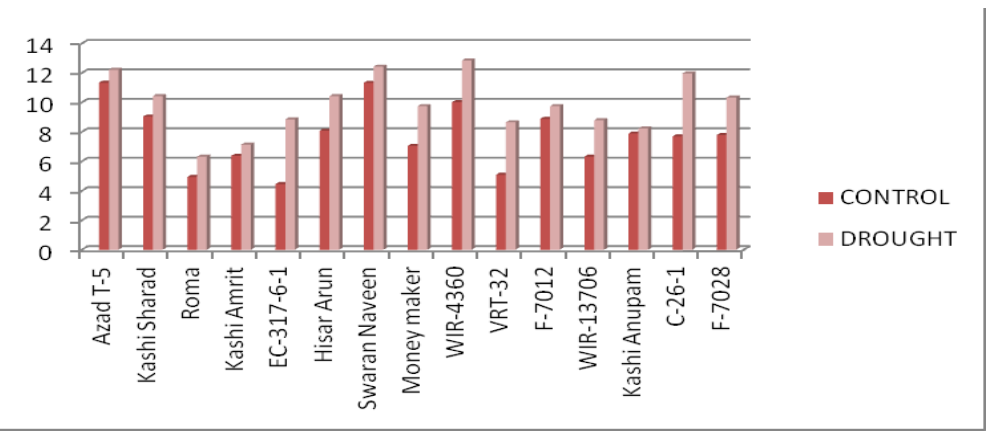

Fig.18 Sugar content of tomato genotypes under drought stress

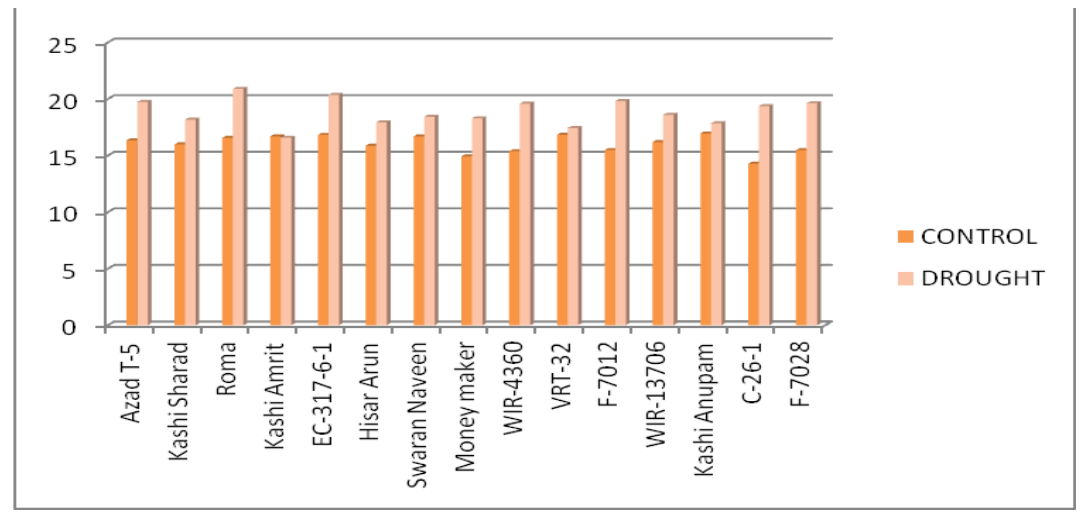

Fig.19 Dendrogram of tomato genotypes under drought stress using ward method (Kashi $\mathrm{A}=$ Kashi Amrit, Kashi An= Kashi Anupam, Kashi sha= Kashi Sharad)

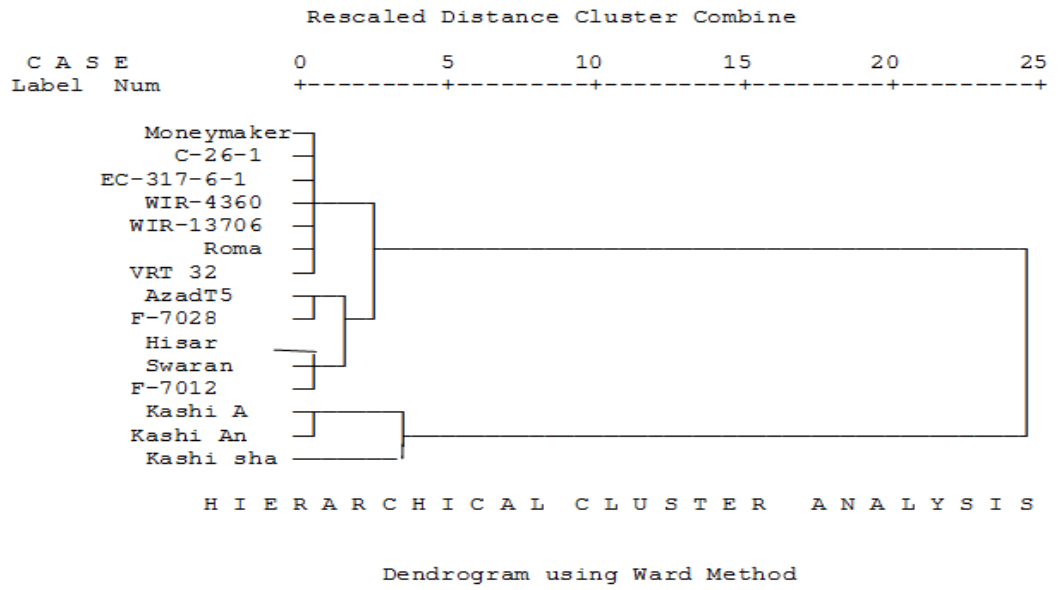

Present study was carried out to screen 15 tomato genotypes with respect to 14 characters. Significant variations /differences for all the 14 characters in 15 tomato genotypes were observed which were used for screening the genotypes of tomato undertaken for the study. Among the morphological characters, under drought stress the widest range $(22.61-99.55 \mathrm{~cm})$ 
was recorded for plant height followed by shoot length (18.60-78.62 cm), root length (3.45$21.17 \mathrm{~cm}$ ), and number of branches (7.3319.00) respectively. Photosynthesis and growth are the most significant processes affected by drought (Sapeta et al., 2012). Drought affects plant growth by diminishing cell division, enlargement and ultimately reduces transport to the root surface which further leads to decrease in plant growth. An early morphological response to drought stress is the avoidance mechanism through adjustment of plant growth rate such as a reduction in shoot height, basal diameter, and total fresh mass in 15 tomato genotypes used in our study. Root length increases as plant was going for adaptation mechanism. Among the yield attributing characters under drought stress the widest range (2.86-43.85) was recorded for number of flowers/plant followed by number of clusters/plant (1.00-8.67), number of fruits/plant (1.00-5.67), and number of flowers/cluster (2.00-4.33). The range of the mean values defines the distance of the potential of different genotypes for various characters studied. The results showed that there was enormous genetic distance between the genotypes for some of the characters like yield and its attributing traits. These results further indicate that if the genotypes are having larger value for range of variability for various characters, there will be better chance to improve the exiting cultivars by different breeding procedures. It can be used in selection or hybridization programme for the respective characters. The result regarding mean and range values obtained in the present investigation are in accordance with the results obtained by (Manna and Paul, 2012; Naz et al., 2013; Nwosu et al., 2014; Biswas et al., 2015).

Optimal leaf area is considered as an important factor to photosynthesis and dry matter yield. Water deficit stress mostly reduced leaf growth and leaf area (Jaleel et al., 2009). Drought stress results into decrease in relative water content, closes stomata and after blocking of stomata will reduce photosynthesis rate. It has been demonstrated that high relative water content is because of more osmotic regulation or less elasticity of tissue cell wall and is a resistant mechanism to drought (Keyvan, 2010). Among the physiological changes in tomato under drought stress, the widest range (60.88-152.60) was recorded for Leaf Area $\left(\mathrm{cm}^{2}\right)$ followed by relative water content (RWC) (47.43-74.83\%), Electrolyte Leakage (conductivity) (75.7892.29\%) and Ratio root shoot length (0.070.41 ), respectively. Plants tolerate $80 \%$ relative water content which is a good criteria for the screening of drought tolerant genotypes. Electrolyte leakage increases imbalance because moisture level was reduced.

Among the antioxidant phytochemicals and osmolyte changes under drought stress the range varied from 10.11 to $49.73 \mu \mathrm{g} / \mathrm{cm}^{2}$ was recorded for chlorophyll content followed by number of Ascorbic Acid 15.66-25.5 mg/100g FLwt, and Carotenoid (58-3.04 mg/100g FLwt), respectively. In osmolytes the widest range was recorded in proline content i.e. $6.32-12.85 \mu \mathrm{g} / \mathrm{g}$ of fresh leaf wt. followed by reducing sugar content i.e. $16.57-20.89 \mathrm{mg} / \mathrm{g}$ fresh wt.

Earlier study by Reddy et al., (2013) evaluated nineteen genotypes of tomato composing of sixteen exotic collections and three varieties of tomato, reporting similar findings in respect to ascorbic acid content. Singh et al., (2003) has shown that ascorbic acid content in 11.21to $53.29 . \mathrm{mg} / 100 \mathrm{~g}$ in fifteen cultivars of tomato. Similar findings, Sharma et al., (1996) demonstrated that ascorbic acid content ranged from 11.21 to $53.29 \mathrm{mg} / 100 \mathrm{~g}$ in 53 genotypes of tomato. The findings are in agreement with Rai et al., (2012).

In mammalian cells, vitamin-C acts as a cofactor for reactions requiring reduced iron and copper metallo-enzymes (Tsao 1997). Considerably high cellular levels of vitamin-C are responsible for antioxidant protection against photosynthetically generated free radicals (Delamere 1996). Moreover, vitamin C plays a role in regenerating other biologically important antioxidants such as glutathione and vitamin $\mathrm{E}$ into their reduced state. 
The carotenoid content in tomato mainly determines its vitamin activity, thus the tomato cultivars were also evaluated for total carotenoids. Significant variation was recorded in the total carotenoid content amongst the 15 tomato genotypes. The total carotenoid content values recorded in this study confirms those reported by Rai et al., (2012) and Singh et al., (2007) who reported that the total carotenoids values varied from 1.00 to $9.47 \mathrm{mg} / 100 \mathrm{~g}$ in 40 tomato genotypes. Raffo et al., (2002) reported that the carotenoids content of tomato were very low at the breaker stage $(1.08 \mathrm{mg} / 100 \mathrm{~g})$, which increased $\geq 10$-fold during ripening and reached $12.705 \mathrm{mg} / 100 \mathrm{~g}$ at full ripening stage. AbdulHammed et al., (2015) demonstrated that the pro-vitamin A index ( $\beta$-carotene) contents ranged between 0.86 and $4.09 \mu \mathrm{g} / \mathrm{g}$ in CherryNasmata while Var-10 tomatoes showed lower range in terms of pro-vitamin A index ( $\beta$ carotene).

Dark red pigment of tomato fruits also contains lesser amount of $\beta$ carotene and other carotenoids. Abdul-Hammed et al., (2015) studied the accumulation pattern of lycopene and beta-carotene in tomato and noted that the maximum concentrations of lycopene (antioxidant index) of 9.42 and $6.68 \mu \mathrm{g} / \mathrm{g}$ were obtained at the Light-red and fully red stages of Cherry-Nasmata and Var-10 tomato cultivars respectively.

Based on the above investigation of morphological characters, yield attributing characters, physiological characters, Antioxidant phytochemicals and osmolytes, the hierarchical cluster was formed which distinguish the 15 genotypes.

Hierarchical cluster analysis was conducted for morphological as well as biochemical traits. Distance between all pairs of genotypes was calculated using Squard Euclidean distance method and genotypes were clustered based on ward's method. Since these clusters are group of individuals possessing similar characters mathematically gathered into the same cluster, these individuals are supposed to exhibit higher external heterozygosity. Cluster analysis based on morphological and biochemical traits were classified into 2 groups one cluster contain only cultivated genotypes and another cluster contain other 12 mixed wild and cultivated genotypes. Now from the 2 clusters 2 wild and 2 other genotypes were selected for the further experiments. The information obtained through clustering may well assist tomato breeders in identifying a limited number of highly differentiated genotypes to be selected for further use in developing suitable variety. Singh et al., (2007) reported that the similar findings in tomato genotypes on basis of morphological and biochemical traits. Rai et al., (2012) were also reported hierarchical cluster analysis in exotic introductions of chilli (Capsicum annuиm L.). Hierarchical cluster analysis on the basis of morphological and biochemical variation in pea (Pisum sativam L.) was reported by Kalloo et al., (2005).

Using morphological, physiological and biochemical characters, fifteen tomato genotypes were screened against drought for identification of tolerant genotype. Among the 15 genotypes, two genotypes i.e. EC-317-6-1 and WIR-4360 were found tolerant to drought in comparison to others. Kashi Amrit and Kashi Sharad were noted susceptible to drought conditions.

It was found that higher proline level, sugar content, carotenoid, and ascorbic acid maintains optimum photosynthesis and RWC under drought, and allowed plants to grow and maintain optimum physiological activity in water stressed condition.

Conclusively, we found that tomato genotypes could differently enhance their ability to struggle their drought. It is possible that proline, chlorophyll, ascorbic acid, caroteniod and sugar content could be used as the effective mechanisms for drought tolerance in tomato genotypes. Furthermore, results demonstrated that the biochemical and physiological parameters are more useful for the screening of drought tolerance of tomato genotypes. 


\section{Acknowledgements}

We are very much thankful to School of Biotechnology, SKUAST-J, India for the financial support provided us for this work.

\section{Author's Contribution}

G.K. Rai has contributed to the experimental conception and design, to the acquisition of data, to the analysis and interpretation of data. Abida Parveena and G.K. Rai have performed most of the experiments and in drafting and revising the manuscript. Abida Parveen, G. K. Rai and Muntazir Mushtaq have contributed to the experiment related to the preparation of phylogenetic tree by using software. G.K. Rai, Abida Parveen, Monica Singh, Muntazir Mushtaq and Ajaz Ahmad Kundoo involved in drafting the manuscript and interpretation of phylogenetic tree. P.K. Rai, R.R. Kumar and S.K. Rai contributed to all related works for data analysis and interpretation of data including statistical analysis. All authors have read and approved the final manuscript.

\section{References}

Abdalla, M.M., and Khoshiban E. 2007 The Influence of Water Stress on Growth, Relative Water Content, Photosynthetic Pigments, Some Metabolic and Hormonal Contents of two Triticium aestivum cultivars. Journal of Applied Sciences Research 3, 2062-2074.

Abdul-Hammed, M., Oke M.O. and Bolarinwa I.F. 2015 Carotenoid accumulation pattern and nutritional indices of Cherry-Nasmata and Var-10 tomato varieties. International Food Research Journal 22, 761-767.

Acero F.J. F., Carbu M., El-Akhal M., Garrido C., Gonzalez- Rodriguez V. E. and Cantoral J.M. 2011 Development of proteomics-based fungicides: new strategies for environmentally friendly control of fungal plant diseases. International Journal of Molecular Science 12, 795-816.

Adams M.D., Kerlavage A.R., Fleischmann
R.D., Fuldner R.A., Bult C.J., Lee, N.H. et al. 2000. Initial assessment of human gene diversity and expression patterns based upon 83 million nucleotides of cDNA sequence. Nature 377, 3-174.

Agenbag, G.A., and Villiers O.T. 1995. Physiological response of spring wheat cultivars to post-anthesis water stress intensity. South African J., Plant and Soil, 12, 27-31.

Agrawal, G.K., and Rakwal, R., 2008. Plant Proteomics: Technologies, Strategies, and Applications. Wiley: Hoboken, N.J.

Agrawal, G.K., Bourguignon J., Rolland N., Ephritikhine G., Ferro M., Jaquinod, M. et al. 2011 Plant organelle proteomics: Collaborating for optimal cell function. Mass Spectrometry Reviews 30, 772-853.

Ahmad, M., Jarillo J.A., Klimczak U., Landry L.G., Peng T., Last, R.L. et al., 1997. An enzyme similar to animal type II photolyase mediates photoreactivation in Arabidopsis. Plant Cell 9, 199-207.

Ahsan, N., Lee D.G., Lee S.H., Kang, K.Y., Bahk, J.D., Choi, M.S. et al., 2007. A comparative proteomic analysis of tomato leaves in response to water logging stress. Physiol Plantarum 131, 555-570.

Alba, R., Fei Z., Payton P., Liu Y., Shanna L.M., Debbie P. C. et al. 2004. ESTs, cDNA microarrays, and gene expression profiling: tools for dissecting plant physiology and development. The Plant Journal 39, 697-714.

Almaghrabi, A.O., 2012 Impact of drought stress on germination and seedling growth parameters of some wheat cultivars. Life Science Journal, 9, 590-598.

Alscher, R.G., and Hess J. L. Antioxidants in Higher Plants, CRC Press, Boca Raton.

Altinkut, A., Kazan, K., Ipekci Z., and Gozukirmizi N. 2001. Tolerance to paraquat is correlated with the traits associated with water stress tolerance in- ii segregating F2 populations of barley and wheat. Euphytica 121, 81-86.

Asada, K., and Takahashi M.1987 Production and scavenging of active oxygen in photosynthesis. Elsevier Science 
Publishers, Amsterdam. 227-287.

Barrs, H.D., and Weatherly P. E. 1962 A reexamination of the relative turgidity technique for estimating water deficits in leaves. Australian Journal of Biological Sciences 15, 413-428.

Bates, L.S., Waldren, R.P., and Teare I.D. 1973 Rapid determination of free proline for water stress studies. Plant Soil 39, 205207.

Baxter, A., Mittler R. and Suzuki N. 2014 ROS as key players in plant stress signaling. $J$. Exp. Bot. 65, 1229-1240.

Bebenek, K., Abbotts J., Roberts J., Wilson S. and Kunkel T. 1989. Specificity and mechanism of error-prone replication by human immunodeficiency virus-I reverse transcriptase. J Biol. Chem. 264, 1694816956.

Ben Hamed, K., Castagna A., Salem E., Ranieri A. and Abdelly C. 2007. Sea fennel (Crithmum maritimum L.) under salinity conditions: a comparison of leaf and root antioxidant responses. Plant Growth Regulation 53, 185-194.

Bennett, R.N., and Wallsgrove R.M. 1994. Secondary metabolites in plant defense mechanisms. New Phytologist 127, 617633.

Blainski, A., Lopes G.C., and de Mello J.C.P. 2013. Application and analysis of the Folin Ciocalteu method for the determination of the total phenolic content from Limonium brasiliense L. Molecules $18,6852-6865$.

Bohnert, H.J., Nelson D.E. and Jensen R. G. 1995. Adaptations to environmental stresses. The Plant Cell 7, 1099-1111.

Bourdon, V., Naef F., Rao P., Reuter V., Mok S., Bosl G. et al. 2002 Genomic and expression analysis of the 12p11-p12 amplicon using EST arrays identifies two novel amplified and over expressed gene. Cancer Res. 62, 6218-6223.

Bowler, C.M., Montagu V., and Inze D. 1992 Superoxide dismutase and stress tolerance, Annu. Rev. Plant Physiol. Plant Mol. Biol. 43, 83-116.

Bradford, M.M., 1976 A rapid and sensitive method for the quantitation of microgram quantities of protein utilizing the principle of protein-dye binding. Analytical Biochemistry 72, 248-254.

Bräutigam, M., Lindlöf A., Zakhrabekova1 S., Chhetri G.G., Olsson B. and Olsson O. 2005 Generation and analysis of 9792 EST sequences from cold acclimated oat, Avena sativa. BMC Plant Biology 5: 18.

Bray, E.A., 1997. Plant responses to water deficit. Trends in Plant Science 2, 48-54.

Bray, E.A., Bailey-Serres J. and Weretilnyk E. 2000. Responses to abiotic stresses. In: Biochemistry and Molecular Biology of Plants (eds. B.B. Buchanan, W. Gruissem and R.L. Jones) 22, 1158-1203.

Burton, G.W., and Ingold K.U. $1984 \beta$ carotene: an unusual type of lipid antioxidant, Science, vol. 224: 569-573.

Cerning, J., and Guilhot J. 1973. Changes in carbohydrate composition during maturation of wheat and barley kernel. Cereal Chem. 50, 220-224.

Chaitante, D., Di, AI, Maiuro L. and Scippa S. G. 2000. Effect of water stress on root meristems in woody and herbaceous plants during the first stage of development, Form, Function and Physiology. Pp. 245258.

Chaves, M. M. 1991 Effects of water deficits on carbon assimilation. J. Exp. Bot. 234, 116.

Chen, J., Wu R., and Yang, P. C. 1998. Profiling expression patterns and isolating differentially expressed genes by cDNA microarray system with colorimetry detection. Genomics. 51, 313-324.

Chen, L., Ding C., Zhao X., Xu J., Mohammad A. A., Wang S. et al. 2015. Differential regulation of proteins in rice (Oryza sativa L.) under iron deficiency. Plant Cell Report 34, 83-96.

Choudhary, P., Rai G.K., Bagati S., Jamwal, D., Bhadwal, D., Shanti, V.R. et al. 2018 Evaluation of Genetic Variability in Tomato (Solanum lycopersicum L. Mill) Genotypes using Microsatellite Markers. Int.J.Curr.Microbiol.App.Sci.7, 23197706. 
Colom, M.R., and VazzanaC. 2003 Photosynthesis and PSII functionality of drought resistant and drought sensitive weeping love grass plants. Environ. Exp. Bot. 49, 135-144.

Cushman, J.C., and Bohnert H. J. 2000 Genomic approaches to plant stress tolerance. Curr. Opin. Plant Biol. 3, 117124.

Dat, J., Vandenabeele S., Vranova E., Van M.M., Inze, D. and Van Breusengem, F. 2000. Dual action of the active oxygen species during plant stress responses. Cellular and Molecular Life Sciences, 57, 779-795.

Delamere, N.A., 1996 Ascorbic acid and the eye sub cell. Journal of Biochemistry 25, 313-329.

Delauney, A., and Verma D. P. S. 1993. Proline biosynthesis and osmoregulation in plants. Plant J. 4, 215-223.

Doke, N., Miura Y., Chai H. B. and Kawakita K., 1991 Involvement of Active Oxygen in induction of plant defense against infection and injury, In: Active Oxygen/Oxidative Stress and Plant Metabolism, Pelt EJ and Steffen K.L. (eds.). American Soc. Plant Physiol. Rockville, M.D. 84-96.

Echols, H., and Goodman M., 1991 Fidelity mechanisms in DNA replication. Annu. Rev. Biochem. 60, 477-511.

Elstner, E., F. 1982. Oxygen activation and oxygen toxicity. Annu. Rev. Plant Physiol. 33, 73-96.

Evers, D., Legay S., Lamoureux D., Hausman J. F., Hoffmann L. and Renaut J. 2012 Towards a synthetic view of potato cold and salt stress response by transcriptomic and proteomic analyses. Plant Molecular Biology 78:503-514.

Ewing, R., Kahla A., Poirot O., Lopez F., Audic S. and Claverie J. 1999. Large-scale statistical analyses of rice ESTs reveal correlated patterns of gene expression. Genome Res. 9, 950-959.

Fernandez, P., Paniego N., Lew S., Esteban H., and Heinz R. A. 2003 Differential representation of sunflower ESTs in enriched organ-specific cDNA libraries in a small scale sequencing project. BMC Genomics.

FAOSTAT 2014. World Production (Tonnes) of Tomatoes in 2013.

Foyer, C.H., Descourvieres, P. and Kumar, K. J. 1994. Protection against oxygen radicals: an important defense mechanism studied in transgenic plants, Plant Cell Environment 17, 507-523.

Fray, R.G. Wallace A., Grierson, D.and Lycett G. W. 1994 Nucleotide sequence and expression of a ripening and water stress related cDNA from tomato with homology to the MIP class of membrane channel proteins. Plant Mol. Biol. 24, 539-543.

Gardner, P.R., and Fridovich I.1991 Superoxide sensitivity of Escherichia coli phosphogluconate dehydratose. Journal of Biological Chemistry266, 1478-1483.

Gerszberg, A., and Hnatuszko-Konka K. 2016 Tomato tolerance to abiotic stress: a review of most often engineered target sequences. Plant Growth Regul. DOI: 10.1007/s10725-017-0251-x

Hakeem, K.R., Chandna R., Ahmad P., Iqbal M. and Ozturk, M. 2012. Relevance of proteomic investigations in plant abiotic stress physiology. OMICS.16: 621-635.

Hare, P.D., Cress W. A. and Staden J. V.1998. Dissecting the roles of osmolyte accumulation during stress. Plant Cell and Environ. 21:535-553.

Hausladen, A., Alscher R. G. and Glutathione., In: Eds. R.G. Alscher, and J.L. Hess. 1993. Antioxidants in Higher Plants. CRC Press, Boca Raton. Pp. 1-3.

Hayata, Y.T., Tabe S. and Kondo I, K. 1998The effects of water stress on the growth, sugar and nitrogen content of cherry tomato fruit. J. Japan. Soc. Hort. Sci.67, 759-766.

Hernandez, I., Alegre L. and Munne-Bosch S. 2004. Drought-induced changes in flavonoids and other low molecular weight antioxidants in Citrus clusii grown under Mediterranean field conditions. Tree Physiol.24, 1303-1311.

Hess, J.L., and Alscher G.R. 1993. Antioxidants in Higher Plants. Vitamin E, $\alpha$-tocopherol 
pp. In:Eds. CRC Press, Boca Raton.111134.

Hong, Z., Kakkenent K., Zhang Z. and Verma D. P. 2000. Removal of feed back inhibition of D-pyrroline-Scarboxylate synthetase results in increased accumulation and protection of plants from osmotic stress. Plant Physiol. 122, 1129-1136.

Imlay, J.A., and Linn S. 1996 DNA damage and oxygen radical toxicity. Science. 240:1302-1309.

Ingram, J. and Bartels D. The molecular basis of dehydration tolerance in plants. Annu. Rev. Plant Physiol. Plant Mol. Biol. 47, 377-403.

Jaleel, C.A., Riadh K., Gopi R., Manivannan P., Ines, J., Al-Juburi, H.J. et al. 2009. Antioxidant defense responses: physiological plasticity in higher plants under abiotic constraints. Acta Physiol. Plant. 31, 427-436.

Jamaux, I., Steinmertz A. and Belhassen E., 1997Looking for molecular and physiological markers of osmotic adjustment in sunflower. New Phytol. 137, 117-127.

Kallo, G., Rai M., SinghJ., Verma A., KumarR. and Rai G.K., 2005. Morphological and biochemical variability in vegetable pea (Pisum sativum L). Veg Sci. 32, 19-23.

Kaufmann, K., Smaczniak C., de Vries, S., Angenent G. C. and Karlova R. 2011 Proteomics insights into plant signaling and development. Proteomics. 11, 744755.

Kawasaki, S., Borchert, C., Deyholos M. Wang H., Susan Brazille A., Kiyoshi K. et al. 2001 Gene Expression Profiles during the Initial Phase of Salt Stress in Rice. The Plant Cell13, 889-905.

Keyvan, S., 2010 The effects of drought stress on yield, relative water content, proline, soluble carbohydrates and chlorophyll of bread wheat cultivars. J. Amin. Plant Sci.8, 1051-1060.

Kramer, P.J., and Boyer J.S. 1995 Water Relations of Plants and Soils. San Diego: Academic
Kramer, P.J., 1969 Plant and soil water relationship: A modern synthesis, McGraw Hill

Kulkarni, M., and Deshpande U. 2007. In vitro screening of tomato cultivars for drought resistance using polyethylene glycol. Afr. J. Biotechnol.6, 691-696.

Kumar, S.G., Mattareddy A. and Sudhakar C. 2003. $\mathrm{NaCl}$ effects on praline metabolism in two high yielding genotypes of mulberry (Morus alba L.) with contrasting salt tolerance. Plant Sci.165, 1245-1251.

Kusvuran, S., and Dasgan, H.Y. 2017. Drought induced physiological and biochemical responses in Solanum lycopersicum genotypes differing to tolerance. Acta Sci. Pol. Hortorum Cultus. 16, 19-27.

Laemmli, U., 1970 Cleavage of structural proteins during the assembly of the head of the bacteriophage T4. Nature. 227, 680685.

Lawlor, D., W. Cornic G. 2002 Photosynthetic carbon assimilation and associated metabolism in relation to water deficits in higher plants. Plant Cell Environ.

Lee, S.C., Lee M.Y. Kim S. J. Jun S. H., Gynheung A. and Seong R. 2005Characterization of an Abiotic Stressinducible Dehydrin Gene, OsDhn1, in Rice (Oryza sativa L.). Mol. Cells.19, 212218.

Lesk, C., Rowhani P. and Ramankutty N. 2016 Influence of extreme weather disasters on global crop production. Nature.529, 84-87.

Li, J., Wu, X. D., Hao, S. T., Wang, X. J., and Ling, H. Q. 2008. Proteomic response to iron deficiency in tomato root. Proteomics. 8, 2299-2311.

Li, Q.B., James., Anderson V. and Charles L., 1994 A cDNA Clone Encoding a Spinach70-Kilodalton Heat-Shock Cognate. Plant Physiol.105, 457-458.

Lindqvist, Y., Branden C. L., Mathews F. S. and Lederer, F. 1991Spinach glycolate oxidase and yeast flavocytochrome b2 are structurally homologous and evolutionary related enzymes with distinctly different function and flavin mononucleotide binding. Journal of Biological Chemistry 
266, 3198-3207.

Macar, T.K., Turan O. and Ekmekcy Y. 2009 Effects of water deficit induced by PEG and $\mathrm{NaCl}$ on chickpea (Cicer arietinum L.) cultivars and lines at early seedling stages. G.U. Journal of Science 22, 5-14.

Manaa, A., Ben Ahmed H., Valot B., Bouchet, J. P., Aschi-Smiti, S., Causse, M.et al. 2011 Salt and genotype impact on plant physiology and root proteome variations in tomato. J Exp Bot. 62, 2797-2813.

Manna, M., and Paul A. 2012 Studies on genetic variability and characters association of fruit quality parameters in tomato. Hort Flora Research Spectrum1, 110-116.

McCord, J.M., and Fridovich I. 1969 Superoxide dismutase. An enzymic function for erythrocuprein (hemocuprein). Journal of Biological Chemistry 244, 6049-6055.

McCue, K.R., and Hanson, A. D., 1990.Drought and salt tolerance: towards understanding and application. Ttetids Biotech.8, 358362.

McKersie, D.B., 1996."Oxidative Stress" Retrieved October 25, 2000 from the World.

Mishra, K.B., Lannacone R., Petrozza A., Mishra A., Armentano N., Vecchia G.L.et al 2012 Engineered drought tolerance in tomato plants is reflected in chlorophyll fluorescence emission. Plant Science. 182, 79-86.

Morgan, J.M., 1997. The death of spikelets in wheat due to water stress. Aust. J. Exp.

Nanjo, Y., Nouri M. Z. and Komatsu S. 2011 Quantitative proteomics analyses of crop seedlings subjected to stress conditions; $a$ commentary. Phytochemistry. 72, 12631272.

Naz, S., Zafrullah A., Shahzadhi K. and Munir N. 2013 Assessment of genetic diversity within germplasm accessions in tomato using morphological and molecular markers. The Journal of Animal \& Plant Sciences23: 1099-1106.

Nishiyama, T., Fujita T. and Shin I. T. 2003 Comparative genomics of Physcomitrella patens gametophytic transcriptome and Arabidopsis thaliana: implication for land plant evolution. Proc. Natl Acad. Sci. USA. 100, 8007-8012.

Nwosu D. J., Onakoya O. A., Okere A.U., Babatunde A.O. and Popoola A.F. 2014. Genetic Variability and Correlations in Rain fed Tomato (Solanum spps.) Accessions in Ibadan, Nigeria. Greener Journal of Agricultural Sciences 4, 211219.

Ogihara, Y., Mochida K., Nemoto Y., Murai K., Yamazaki Y., Shin I. T. et al., 2003. Correlated clustering and virtual display of gene expression patterns in the wheat life cycle by large-scale statistical analyses of expressed sequence tags. Plant J.33, 1001-1011.

Paterson, A., Bowers J., Burow M., Draye X., Elsik C. G., Chun-Xiao J. et al. 2000 Comparative genomics of plant chromosomes, Plant Cell 12, 1523-1540.

Premachandra, G.S., Saneoka H., Fujita K. and Ogata S. 1990. Water stress and potassium fertilization in field grown maize ( $\mathrm{Zea}$ mays L.): effects of leaf water relations and leaf rolling. Journal of Agronomy and Crop Science. 170, 195-201.

Price, A., Lucas P. W. and Lea P. J. 1990. Age dependent damage and glutathione metabolism in ozone fumigated barley: A leaf section approach. Journal of Experimental Botany 41, 1309-1317.

Raffo, A., Leonardi C., Fogliano V., Ambrosino P., Salucci M., Gennaro L. et al. 2002. Nutritional value of cherry tomatoes (Lycopersicon esculentum Cv. Naomi F1) harvested at different ripening stages. Journal of Agricultural Food Chemistry 50, 6550-6556.

Rahman, S.M. L., Mackay W. A., Quebedeaux B., Nawata E., Tetsuo S. and Mesbahuddin A. S. M. 2000 Superoxide Dismutase Activity, Leaf Water Potential, Relative Water Content, Growth and Yield of a Drought-Tolerant and a Drought-Sensitive Tomato (Lycopersicon esculentum Mill.) Cultivars. Subtropical Plant Science 54:16-22. 
Rai, G.K., Kumar R., Singh A. K., Rai P. K. Rai, M., Chaturvedi A. K. and Rai A. B. 2012 Changes in antioxidant and phytochemical properties of tomato (Lycopersicon esculentum mill.) under ambient condition. Pakistan Journal of Botany 44, 667-670.

Ramakrishna, A., and Ravishankar G.A. 2011 Influence of abiotic stress signals on secondary metabolites in plants. Plant Signal.Behav.6, 1720-1731.

Ranganna, S. 1977. Manual for Analysis of Fruit , and Vegetable Products. Tata McGraw Hill Publishing Company Limited. New Delhi. 634.

Ray, J.D., and Sinclair T. R., 1998. The effect of pot size on growth and transpiration of maize and soybean during water deficit stress.J. Exp. Bot. 49, 1381-1386.

Raiola, A., Rigano M. M., Calafiore R., Frusciante L. and Barone A. 2014 Enhancing the Health-Promoting Effects of Tomato Fruit for Biofortified Food. Mediators of Inflammation. http://dx.doi.org/10. 1155/2014/139873.

Reddy, B.R., Reddy M. P., Begum H. and Sunil N. 2013. Genetic diversity studies in tomato (Solanum lycopersicum L.). Journal of Agriculture and Veterinary Science4: 53-55.

Rick, C.M., 1978. The tomato. Sci Am. 239: 76-87.

Roberts, J., Preston B., Johnston L., Soni A., Loeb L. and Kunkel T. 1989. Fidelity of two retroviral reverse transcriptases during DNA-dependent DNA synthesis in vitro. Mol. Cell. Biol. 9, 469-476.

Rogaev, E., Sherrington R. and Rogaeva E. 1995. Familial Alzheimer's disease in kindreds with missense mutations in a gene on chromosome 1related to Alzheimer's disease type 3 gene. Nature, 376, 775-778.

Rokka, A., Zhang L. and Aro E. M. 2001. Rubiscoactivase: an enzyme with a temperature-dependent dual function. Plant J.25, 463-471.

Ronning, C., and Stegalkina S. 2003. Comparative analyses of potato expressed sequence tag libraries. Plant Physiol 131, 419-429.

Saccardy, K.B., Pineau O., Roche. And Cornic G. 1998. Photo chemical efficiency of photosystem and xanthophyll cycle components in Zea mays leaves exposed to water stress and high light. Photosy. 56: 57-66.

Sairam, R.K., 1994. Effect of moisture stress on physiological activities of two contrasting wheat genotypes. Indian Journal of Experimental Biology 32: 594-597.

Sairam, R.K, Tyagi A. 2004 Physiology and molecular biology of salinity stress tolerance in plants. Current Science. 86, 407-421.

Sanchez-Blanco, J., Fernandez T. A. Morales A., MorteJ. J. Alarcon, 2006. Variation in water stress, gas exchange, and growth in Rasmanrins officinalis plants infected with Glamus deserticola under drought conditions. J. Plant Physiol. 161, 675-682.

Sanchez-Rodriguez E., Rubio-Wilhelmi M. M., Cervilla, L. M., Blasco B, R., Ios J.J., Rosales, M. A. et al., 2010. Genotypic differences in some physiological parameters symptomatic for oxidative stress under moderate drought in tomato plants. Plant Sci. 178, 30-40.

Sanjaya Chan. M.T., 2005. Advances in Agrobacterium Mediated Transformation in Tomato - an Overview. Journal of Genetics and Molecular Biology 16, 211224.

Sapeta H., Costa J.M., Lourenco T., Maroco J., Van der Linde P. and Oliveira M.M. 2013. Drought stress response in Jatropha curcus: growth and physiology. Environ. Exp. Bot. 85, 76-84.

Seki, M., Narusaka M., Ishida J., Nanjo T., Fujita M., Oono Y. et al. 2002. Monitoring the expression profiles of 7000 Arabidopsis genes under drought, cold and high-salinity stresses using a full-length cDNA microarray. Plant J. 31, 279-292.

Seki, M., Narusaka M., Abe H., KasugaM., Yamaguchi-Shinozaki K. and Carninci P. 2001. Monitoring the expression pattern of 1,300 Arabidopsis genes under drought 
and cold stresses by using a full-length cDNA microarray. Plant Cell. 13, 61-72.

Sharma, S., Mahajan R. and Bajaj K. L.1996. Biochemical evaluation of some tomato varieties. Vegetable Science, 23, 42-7.

Shinozaki K, and Yamaguchi-Shinozaki K. 2000. Molecular responses to dehydration and low temperature: Differences and cross-talk between two stress signaling pathways. Current Opinion of Plant Biology. 3, 217-223.

Silva, F., G.D., Iandolino A., Kayal F. A., Bohlmann M. C., Cushman M. A., Lim H.et al. 2005. Characterizing the Grape Transcriptome Analysis of Expressed Sequence Tags from Multiple Vitis Species and Development of a Compendium of Gene Expression during Berry Development. Plant Physiology139: 574-597.

Singh, J., Rai G. K., Upadhyay A. K. and Singh K. P 2003. Antioxidents phytonutrients in tomato (Lycopersicon esculentum Mill.). Indian Journal of Agricultural Sciences, 74, 1-4.

Singh, J., Rai M., Kumar R., Verma A. and Rai G. K. 2007. Genotyping variation and hierarchical clustering of tomato (Lycopersicon esculentum Mill.) based on morphological and biochemical traits. Vegetable Sciences. 34, 40-45

Smirnoff, N., Plant resistance to environmental stress. Curr. Opin. Biotech. 9.

Smirnoff, N., and Cumbes Q. J. 1989 Hydroxyl radical scavenging activity of compatible solutes. Phytochem. 28, 1057-1060.

Solankey, S.S., Singh R.K. and Baranwal D.K. 2015. Genetic Expression of Tomato for Heat and Drought Stress Tolerance: An Overview. International Journal of Vegetable Science 21, 496-515.

Stadtman, E.R., 1986 "Oxidation of proteins by mixed-function oxidation systems.

Statistical Yearbook of the Food and Agricultural Organisation for the United Nations. 2013.

States Departments of Horticulture and Agriculture. Horticulture Statistics Division Department of Agriculture,
Cooperation \& Farmers Welfare Ministry of Agriculture \& Farmers Welfare Ministry of Agriculture \& Farmers Welfare Government of India New Delhi. Monthly Report Tomato, January 2018.

Thelen, J.J., and Peck S.C. 2007. Quantitative proteomics in plants: choices in abundance. Plant Cell.19, 3339-33346.

Thimmaiah, S.K., 1999. Standard method of Biochemical analysis. Kalyani Publisher, New Delhi.

Thomashow, M.F., 2001. So what's new in the field of plant cold acclimation? Lots! Plant Physiology 125:89-93.

Tsao, C.S., 1997. An overview of ascorbic acid chemistry and biochemistry. (In) Packer, L. and Fuch, J. (eds). Vitamin C in health and diseases. Marcal Dekker, New York.

Van der Hoeven, R., Ronning C., Giovannoni J., Martin G. and Tanksley S. 2002. Deductions about the number, organization, and evolution of genes in the tomato genome based on analysis of a large expressed sequence tag collection and selective genomic sequencing. Plant Cell. 14, 1441-1456.

Van der Hoeven, R., Ronning C. Giovannoni J., Martin G. and Tanksley S. 2002 Deductions about the number, organization, and evolution of genes in the Tomato genome based on analysis of a large Expressed Sequence Tag collection and Selective Genomic Sequencing. The Plant Cell, 14, 1441-1456.

Verbruggen, N. and Hermans, C., 1996 Proline accumulation in plants: a review. Amino Acids35, 753-759.

Wang, W., Vinocur B., Shoseyov O. and Altman A. 2004 Role of plant heat-shock proteins and molecular chaperones in the abiotic stress response. Trends Plant Sci.9, 244-52

Yamaguchi-Shinozaki, K., and Shinozaki K. 2002 Characterization of the expression of a desiccation responsive $r d 29 A$ gene of Arabidopsis thaliana and analysis of its promoter in transgenic plants .Mol Gen Genet. 236, 331-340.

Yancy, P.H., Cark M. E., Hand S. C., Bowlus 
R. D. and Somero G. N. 1982. Living with water stress: evolution of osmolyte systems. Science 217, 1214-1223.

Yang, L., Bai X., Yang Y., Ahmad P., Yang Y. and $\mathrm{Hu} \mathrm{X}$. 2011. Deciphering the protective role of nitric oxide against salt stress at the physiological and proteomic levels in maize. Journal of Proteome Research 10, 4349-4364.

Yemm, E.W., and Willis, A.J., 1954. The estimation of carbohydrates in plant extracts by anthrone. Biochem. J. 53, 508514.

Yokthongwattana, C., Mahong, B., Roytrakul S., Phaonaklop N., NarangajavanaJ. and Yokthongwattana, K. 2012. Proteomic analysis of salinity-stressed revealed differential suppression and induction of a large number of important housekeeping proteins. Planta 235 (3), 649-659.

YoshibaY, T., Kiyosea, K., Nakashima K., Yamaguchi-shinozaki. And Shino-zaki K. 1997Regulation of levels of proline as an osmolyte in plants under water stress. Plant Cell Physiol. 38, 1095-1102.

Zhang, C., X., Fu J. H., Cheng S. Z. and Lin F. Y. 2009 Greater vegetable and fruit intake is associated with a lower risk of breast cancer among Chinese women. International Journal of Cancer 125, 181188.

Zhang, H., Han B., Wang T., Chen S., Li, H., Zhang Y. and Dai S.2012. Mechanisms of plant salt response: Insights from proteomics. Journal of Proteome Research 11: 49-67.

\section{How to cite this article:}

Abida Parveen, Gyanendra Kumar Rai, Muntazir Mushtaq, Monika Singh, Pradeep K. Rai, Sunil K. Rai and Ajaz Ahmad Kundoo. 2019. Deciphering the Morphological, Physiological and Biochemical Mechanism Associated with Drought Stress Tolerance in Tomato Genotypes. Int.J.Curr.Microbiol.App.Sci. 8(05): 227-255. doi: https://doi.org/10.20546/ijcmas.2019.805.028 